\title{
A Justiça Parcial e a Ganância enquanto virtude e vício do caráter na Ética a Nicômaco: ação interpessoal, emoção e prazer
}

\author{
André Luiz Cruz Sousa
}

The aim of this paper is to study a set of three issues related to the understanding of partial justice and partial injustice as character dispositions, namely the distinctive circumstance of action, the emotion involved therein and the pleasure or pain following it. Those points are treated in a relatively obscure way by Aristotle, especially in comparison with their treatment in the expositions of other character

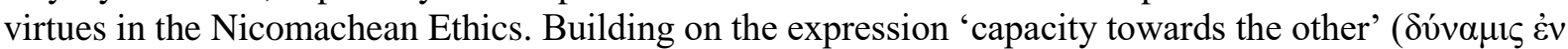
$\tau \tilde{\omega} \pi \rho o_{\varsigma}$ ह̌ $\left.\tau \varepsilon \rho o v\right)$, the paper highlights the interpersonal nature of the circumstances of just and unjust

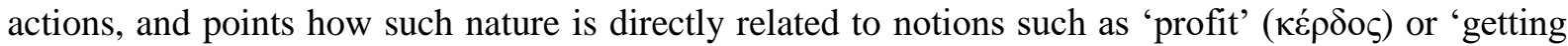

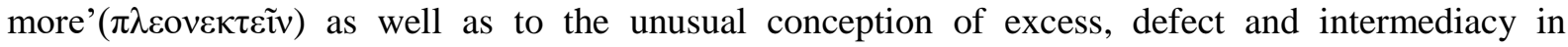
Nicomachean Ethics Book V. The interpersonal nature of just and unjust actions works also as the starting-point for the interpretation both of the pleasure briefly mentioned in $1130 \mathrm{~b} 4$ as characterizing the greedy person and of the emotion involved in acting justly or greedy, which is mentioned in an extremely elliptical way in 1130b1-2: the paper argues, on the one hand, that the pleasure felt in acting justly or unjustly concerns not only the goods that are the object of just or unjust interactions, but also the way such interactions affect the people involved; on the other hand, it argues that the emotion actuated in just or unjust interactions relates to the agent's concern or lack of concern with the good of those people.

\section{Introdução ${ }^{1}$}

O objetivo desse estudo é articular um conjunto de questões necessárias à compreensão da Justiça Parcial e da Ganância enquanto disposições do caráter. Nos livros III e IV da Ética a Nicômaco, observa-se o seguinte padrão no tratamento das diversas disposições de caráter: um estudo do tipo de circunstância de ação que caracteriza cada uma das virtudes e vícios, a emoção envolvida no exercício de tais ações e o prazer ou o desgosto que advém aos agentes. O estudo

\footnotetext{
${ }^{1}$ Esse artigo é fruto de pesquisa realizada junto ao Programa de Pós-Graduação em Filosofia da UEM, com apoio financeiro da CAPES (PNPD). Agradeço em especial a Mateus Ricardo Fernandes Ferreira (UEM), Lucas Angioni (UNICAMP) e Breno Zuppolini (UNIFESP) pelas observações críticas que me fizeram quando apresentei minha pesquisa para professores e estudantes de filosofia nessas duas universidades.
} 
da justiça no livro V não segue inteiramente esse padrão. Ao invés de expor detalhadamente a conduta moral do agente justo e do agente injusto, Aristóteles se preocupa sobretudo em descrever uma série de práticas institucionais: distribuição, punição dos crimes, as trocas comerciais, etc. E com isso a exposição da Justiça Parcial e da Ganância termina sendo uma exposição de certo modo desprovida daqueles pontos explicitamente discutidos na exposição das demais disposições do caráter. Por isso, quando o intérprete se debruça sobre a Justiça Parcial e a Ganância, tentando compreendê-las à luz da caracterização geral das virtudes e vícios do caráter por Aristóteles, ele se depara com algumas perplexidades. Essas perplexidades correspondem aos três elementos presentes no título desse estudo: ação, emoção e prazer.

A ação característica da Justiça Parcial, isto é, a conduta moral do agente justo, é exposta no início do livro V (Ethica Nicomachea 1130a14-b5). Trata-se de uma exposição vaga e insuficiente, de sorte que é necessário recorrer a outras passagens do texto para compreendêla com mais clareza. Em outras palavras, o tratamento da conduta justa e da conduta injusta está esfacelado ao longo de diversos pontos do livro V, não havendo uma exposição contínua, completa e coesa dessa conduta. No que diz respeito ao prazer e à emoção envolvidos nos atos de justiça parcial, a situação é ainda mais complicada para o intérprete. Há uma observação (1130b4) sobre o prazer experimentado pelo agente ganancioso ou injusto, que Aristóteles faz en passant, e simplesmente não há um tratamento explícito da emoção na esfera da justiça. Existe somente (aquilo que em minha interpretação eu defendo ser) uma alusão à emoção envolvida nas ações justas e gananciosas; essa alusão se encontra na expressão "capacidade

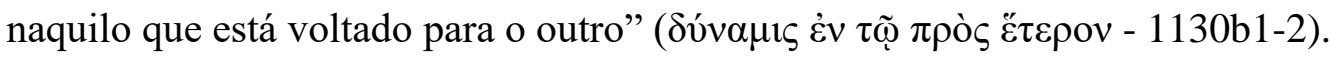

Tendo em vista esse contexto de relativa escassez de material, a leitura do livro V que eu proponho no presente estudo visa fazer avançar o estado da questão na direção da elaboração de um quadro mais nítido da justiça parcial e da ganância enquanto disposições de caráter. Tal quadro seria o resultado da articulação dos três tópicos mencionados no título: ação, emoção e prazer. Nesse sentido, o estudo percorre os passos seguintes: um exame do texto de 1130a14b5, que contém a exposição da virtude da justiça parcial e do vício da ganância (I); a articulação da ação característica dessas disposições como ação eminentemente interpessoal (II); o exame do prazer envolvido em tais ações (III); uma discussão a respeito do seu aspecto emocional (IV).

I. E.N. 1130a14-b5: a Justiça Parcial é estabelecida como virtude distinta da Justiça Geral 
Journal of Ancient Philosophy ISSN 1981-9471 - FFLCH/USP www.revistas.usp.br/filosofiaantiga
J. anc. philos. (Engl. ed.), São Paulo, v.13, n.2. p. 109-145, 2019.

DOI: http://dx.doi.org/10.11606/issn.1981-9471.v13i2p109-145

Os três componentes constantes do estudo aristotélico das virtudes do caráter que eu mencionei na introdução - circunstância característica de ação, a emoção que acomete o agente no momento da ação, e o prazer ou a dor que acompanham essa emoção - podem ser vislumbrados no início do segundo capítulo do livro V, momento em que Aristóteles começa a tratar da justiça parcial. Nesse sentido, pode-se afirmar que o propósito dessa passagem, 1130a14-b5, é estabelecer a Justiça Parcial enquanto uma virtude do caráter específica, distinta das demais. Antes desse texto nós encontramos uma única observação significativa a respeito da ação característica da justiça parcial: ao acusar a existência de homonímia na esfera da justiça - o ponto de partida para a separação entre justiça geral e justiça parcial $^{2}$ - Aristóteles atribui à justiça parcial tudo quanto diga respeito à igualdade (1129a26-b1). O ato típico dessa virtude é chamado de "igual" ( $\tau$ ò ǐ $\sigma o v)$, e aquele homem propenso a praticá-lo é chamado de "equânime" (ó ľ́os). Por sua vez, o ato típico do vício correlato, a injustiça parcial ou ganância, é nomeado

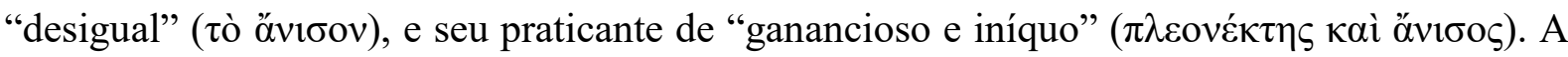
circunstância característica das ações de justiça parcial são, portanto, as relações de igualdade longamente descritas no livro V, e a ação característica da ganância seria aquela ação que rompe o equilíbrio dessas relações e as torna desiguais. ${ }^{3}$

O texto de 1330a14-b5 antecede a exposição das diferentes modalidades de relação de igualdade. Seu cerne é o exame das práticas justas e injustas enquanto condutas morais, em especial a relação entre o caráter justo ou injusto e as ações que os atualizam. Tal como afirmado na introdução, há variedade quanto à clareza com a qual cada uma das três questões que me interessam é ali exposta: a ação típica da justiça parcial, assim como a ação oposta que

\footnotetext{
${ }^{2}$ Não discuto a questão da homonímia da justiça nesse artigo, visto que me ocupo apenas da virtude da justiça parcial. Por essa razão eu me limito a tomar como ponto de partida a separação efetuada entre justiça geral e justiça parcial logo no início do livro V, mais precisamente em 1129a23-1129b1. Discutese na literatura secundária qual seria a relação entre as duas virtudes que, embora compartilhem o mesmo nome, são diferentes. Seriam elas simplesmente homônimas, i.e., compartilham acidentalmente um nome? Ou haveria alguma proximidade entre as duas justiças, a despeito da diferença que entre elas subsiste? Gauthier \& Jolif e Jackson, por exemplo, sustentam que justiça parcial e justiça geral seriam duas espécies distintas dentro de um mesmo gênero, a saber, o das virtudes relacionais. Ver Gauthier \& Jolif, Aristote. L'Éthique à Nicomaque. Tome II - Premiére Partie. Commentaire. Livres I-V, (Éditions Peeters, 2002, p.333-334) e Jackson, H. The Fifth Book of the Nicomachean Ethics of Aristotle. (Cambridge University Press, 1879, p.72). Zingano, por outro lado, defende que a justiça parcial seria uma espécie do gênero chamado de justiça geral. Ver Zingano, M. Ethica Nicomachea V 1-15: Tratado da Justiça. Estudo, Tradução e Comentários. (São Paulo: Odysseus, 2017, p.170-171).

${ }^{3}$ Ver Kraut, R. Aristotle. Political Philosophy. (Oxford University Press, 2002, p.102-103; 154-160), além de Zingano (2017, p.160,170-173) e Gauthier \& Jolif (2002, p.335-336).
} 
caracteriza o vício da ganância, são articuladas com relativa clareza no texto; a existência de prazer no exercício dessas ações é mencionada explicitamente, muito embora não haja qualquer tentativa de explicar o modo como esse prazer advém ao agente quando esse se põe a agir com justiça ou injustiça; a emoção, por fim, não é mencionada explicitamente, e a minha interpretação sugerirá adiante a possibilidade de que haja apenas uma alusão à emoção envolvida nas ações justas e injustas, alusão que estaria contida na expressão "capacidade com

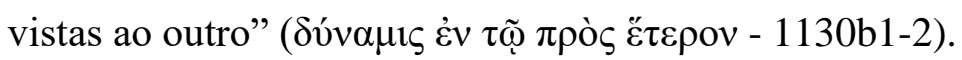

A importância da passagem 1130a14-b5 para o argumento a ser aqui desenvolvido justifica a sua citação integral no corpo do texto. Com o intuito de tornar o seu exame o mais claro possível, facilitando a referência precisa a cada sentença, a passagem será dividida em três partes - chamadas, respectivamente P1, P2 e P3 - e as sentenças serão numeradas, começando com [1], a primeira sentença de P1, e finalizando com [11], a última sentença de P3. Optei pela numeração unificada e contínua das sentenças ao longo das três passagens para enfatizar a continuidade textual entre P1, P2 e P3. Chamo o conjunto formado pelas três de P1P2-P3. Além disso, a repartição do texto em três passagens corresponde ao que entendo serem os três passos da exposição que Aristóteles faz da justiça parcial e da ganância.

O primeiro passo da exposição é afirmar a existência de uma virtude da justiça que é diferente da justiça entendida como virtude completa (aquela chamada tradicionalmente de 'justiça geral'). O final do primeiro capítulo do livro $\mathrm{V}$ fora dedicado à descrição da justiça geral e, ao iniciar o segundo capítulo do livro V, Aristóteles afirma que existem ações justas e injustas que pertencem a um outro domínio de ações. Eis $\mathrm{P}^{4}$ (1130a14-24):

\section{P1}

[1] Buscamos, com efeito, a justiça que é uma parte da virtude: existe uma tal virtude, como nós dizemos. [2] De modo semelhante se dá quanto à injustiça parcial. [3] O sinal de que isso é assim: segundo os demais vícios, o agente comete injustiça sem tirar nenhuma vantagem, por exemplo, aquele que atirou o escudo em razão da covardia ou expressou-se com insultos em razão da irascibilidade ou não ajudou outrem com dinheiro em razão da avareza. [4] Mas, quando quer que tire vantagem, não o faz segundo algum desses vícios, e tampouco com relação a todos, mas o faz segundo um determinado vício - pois nós o censuramos - a saber, conforme a injustiça. [5] Há, portanto, alguma outra injustiça que é parte do vício total, e um ato injusto que é parte do ato injusto total ou do ato ilícito.

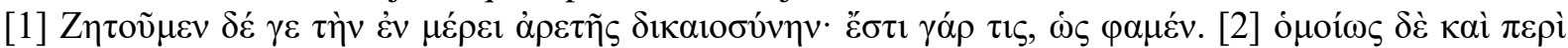

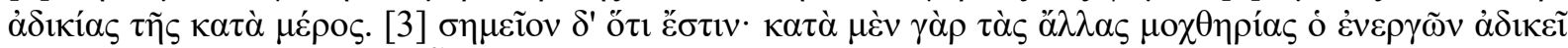

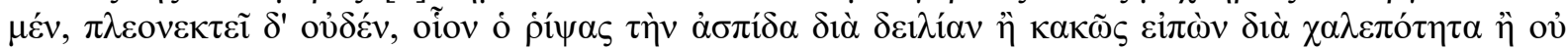

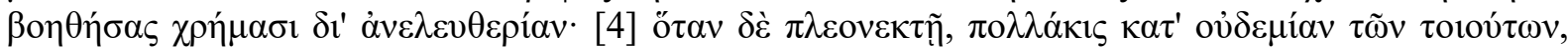

\footnotetext{
${ }^{4}$ A tradução dos textos gregos no artigo é minha. A edição da Ética a Nicômaco é I.Bywater (1894). Aristotelis Ethica Nicomachea. Oxford Classical Texts.
} 
Journal of Ancient Philosophy ISSN 1981-9471 - FFLCH/USP www.revistas.usp.br/filosofiaantiga
J. anc. philos. (Engl. ed.), São Paulo, v.13, n.2. p. 109-145, 2019.

DOI: http://dx.doi.org/10.11606/issn.1981-9471.v13i2p109-145

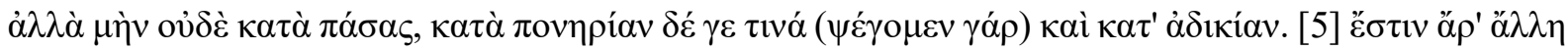

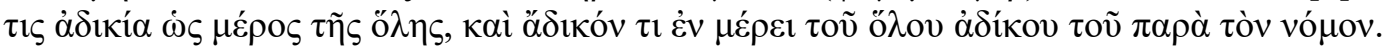

A passagem inicia, em [1], com a enunciação da existência de uma outra virtude da justiça, a ser agora investigada, e com a afirmação feita em [2] de que existe também um outro

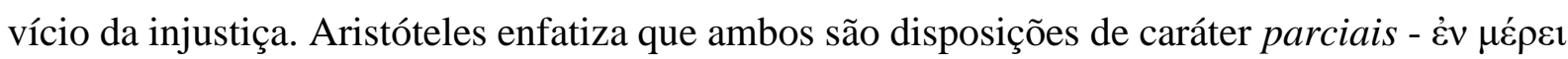

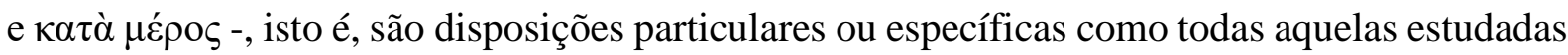
nos livros III e IV do tratado. Em P1[5] está estabelecida a existência dessas duas disposições. O cerne do argumento está nas sentenças [3] e [4], onde se encontram os subsídios que permitem passar da enunciação da existência para a afirmação de que essa existência está provada. Em

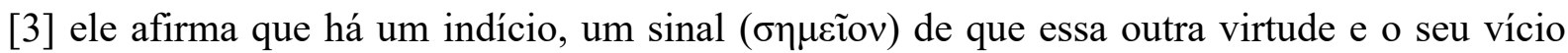
correlato existem. Aristóteles se refere ao fato de em algumas ações injustas acontece que o agente "tire vantagem" ( $\pi \lambda \varepsilon$

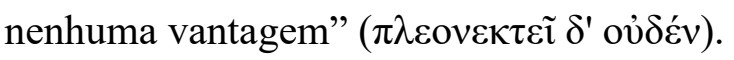

Em [3] nós nos deparamos com exemplos das ações injustas nas quais o agente não tira nenhuma vantagem, que são as ações de injustiça geral. Sabemos isso porque o teor do texto é fortemente dependente da exposição da justiça geral no primeiro capítulo do livro V (1129b1127), onde Aristóteles conecta a prática de uma série de ações - atirar fora o escudo, falar de modo insultuoso ou recusar socorro financeiro - tanto à injustiça geral quanto a outros vícios, respectivamente à covardia, à irascibilidade e à avareza. P1[3] é, portanto, uma referência oblíqua à caracterização da justiça geral como uma virtude completa. Tal completude da justiça geral decorre da sua sobreposição com todas as virtudes parciais em razão do escopo amplo das leis, que alcançam toda a moralidade ${ }^{5}$, comandando a prática das ações virtuosas e coibindo a

\footnotetext{
${ }^{5}$ MacIntyre apresenta uma interpretação interessante para a relação entre a violação da justiça geral (= cometer um ilícito) e a incapacidade de agir segundo as diversas virtudes parciais (= ser deficiente no caráter): "[...] although someone who possesses the virtues to a high degree will be far less apt than others to commit grave offences, a brave and modest man may on occasion commit murder and his offence is no less and no more than the offence of a coward or a braggart. To do positive wrong is not the same as to be defective in doing or being good. Nonetheless the two kinds of failure are intimately related. For both injure the community to some degree and make its shared project less likely to be successful. An offence against the laws destroys the relationships which make common pursuit of the good possible; defective character, while it may also render someone more liable to commit offences, makes one unable to contribute to the achievement of that good without which the community's common life has no point". Itálicos meus. Ver MacIntyre, Alasdair. After Virtue. A Study in Moral Theory. (University of Notre Dame Press 1984, p.152).
} 
prática das ações viciosas. ${ }^{6}$ Atendo-nos aos exemplos mencionados em [3], aquele que atira fora o escudo, isto é, deserta, comete um ato de covardia enquanto teme inapropriadamente a luta e também um ato de injustiça, na medida em que viola a lei que proíbe a deserção; aquele que insulta os outros por meio de palavras comete um ato de irascibilidade enquanto deixa-se dominar por uma raiva inapropriada, e também um ato de injustiça em razão da lei proibir o uso insultuoso do discurso - o exemplo de Aristóteles é vago, mas é provável que ele esteja fazendo referência a crimes como calúnia, difamação, injúria, etc.

Encontramos, por fim, em P1[4] a descrição das ações de justiça que pertencem a um departamento peculiar, e que não possuem aquela sobreposição com outros vícios que caracteriza os atos de injustiça geral. Trata-se de ações que são simplesmente injustas. Aristóteles enfatiza que o vício que engendra o tipo de ação mencionado em P1[4] não é um vício completo (tal como o é a injustiça geral), afirmando que tais ações não são praticadas

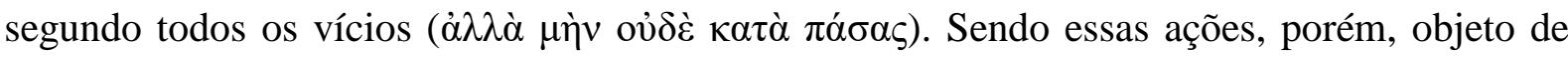
censura, elas devem ser atribuídas a algum vício específico, parcial como todos os vícios estudados nos livros III e IV da Ética a Nicômaco: tais ações ocorrem "segundo algum vício, a

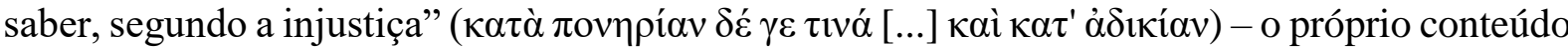

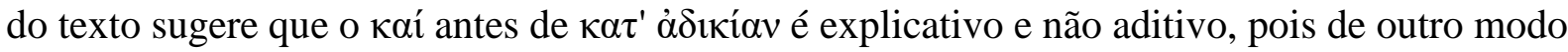
essa injustiça não seria uma virtude parcial. Por fim, [4] afirma que o traço característico desse domínio peculiar de ações injustas e somente injustas é o fato de que o agente tira vantagem ao praticá-las.

P2 (1130a24-32) contém o segundo passo da tentativa de Aristóteles de estabelecer a Justiça Parcial como uma virtude do caráter peculiar. Estabelecida a existência dessa virtude, ele propõe uma comparação entre uma ação de injustiça parcial e outra de injustiça geral:

\section{P2}

[6] Além disso, se um homem pratica o adultério com vistas a obter o proveito que angaria, ao passo que outro o faz por causa do apetite, desembolsando dinheiro e sendo punido, esse último parece ser antes intemperante do que ganancioso, enquanto que o outro é injusto, mas não intemperante: pois é manifesto que agiu para obter proveito. [7] De resto, no que concerne a todos os demais atos injustos existe sempre a referência a algum vício, por exemplo, se alguém cometeu adultério, à intemperança, se

\footnotetext{
${ }^{6}$ Eis a observação de Schofield a respeito da justiça geral: "The virtue constituted by justice delineated here is not for Aristotle just one among the other virtues. It is a super-virtue or meta-excellence which requires the exercise of many other fundamental virtues. Aristotle explains how the provisions of the law itself make demands that can be met only by behaving in ways characteristic of the courageous person, the restrained person, the mild person, and so on". Ver Schofield, Malcom. "Aristotle's Political Ethics" in KRAUT, R. (org.). The Blackwell Guide to Aristotle's Nicomachean Ethics. (Blackwell Publishing, 2006, p.315).
} 
abandonou a guarnição, à covardia, se cometeu uma agressão, à ira; se obteve proveito, a nenhum outro senão à injustiça".

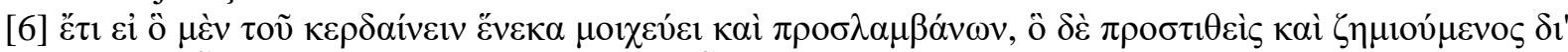

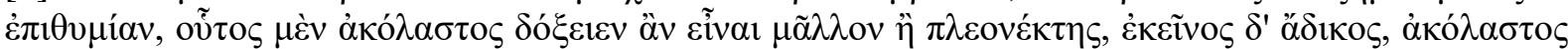

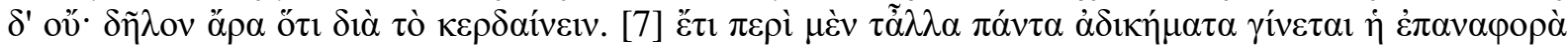

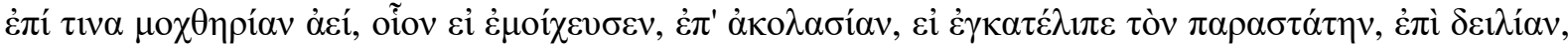

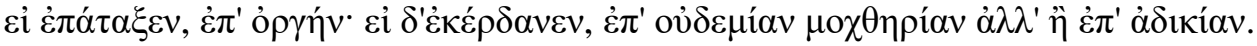

A opção por cotejar dois atos de adultério em [6] indica que o intuito de Aristóteles é enfatizar a diferença entre injustiça parcial e geral, mesmo em circunstâncias cuja natureza tende a dificultar a compreensão dessa diferença. $O$ adultério que é ato de injustiça geral é descrito como um ato não somente de injustiça, mas também de intemperança. A pessoa que o

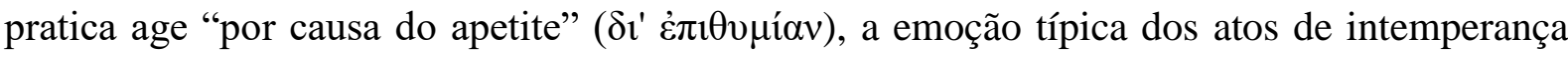
(1103b17-21; 1118b8-1119a20); trata-se, por isso, de pessoa intemperante, mas não de pessoa gananciosa. Ou seja, o agente não é injusto no sentido parcial, mas no sentido geral de injustiça: é injusto enquanto desobedece às leis que proíbem o adultério, e é intemperante enquanto age sob influência desmedida do apetite. Há uma alusão àquela conexão necessária entre Injustiça Geral e demais vícios na afirmação feita em P2[7] de que nos atos de injustiça geral "sempre

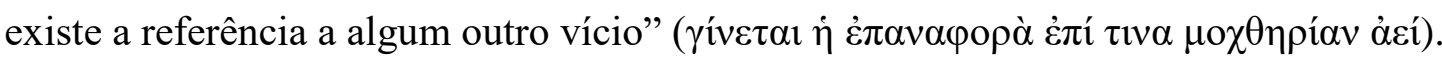

Já o adultério que é um ato de injustiça parcial, caracteriza-se pelo fato de que o agente o comete "com vistas a obter proveito" ( é intemperante. A busca do proveito, somada à ausência da referência ao vício da intemperança,

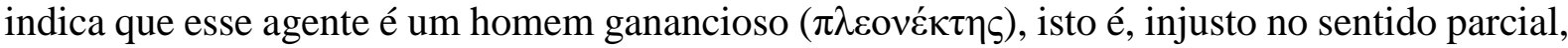
conclusão que as observações feitas em P1 [3] e [4] ajudam a sustentar. A afirmação de que tal agente não é intemperante é importante para a caracterização do vício da ganância: a busca pelo proveito substitui a busca pela satisfação do apetite sexual, que seria a motivação mais usual do adultério. Essa substituição parece ser confirmada pela observação feita no final de P2[7] de que, no caso em que a pessoa vem a obter proveito na ação injusta, inexiste então a referência a qualquer vício diferente da própria injustiça.

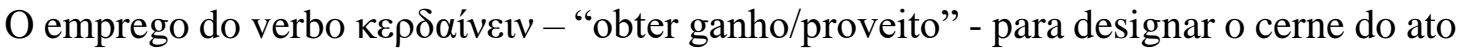
de injustiça parcial parece tornar a descrição desse ato menos vaga do que aquela descrição que

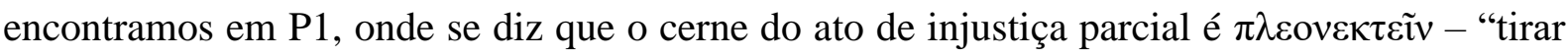

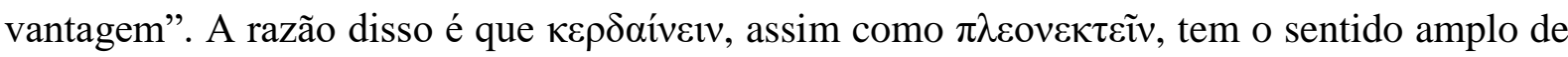
ganho, mas tem também um sentido mais específico de ganho pecuniário, em particular de um 
Journal of Ancient Philosophy ISSN 1981-9471 - FFLCH/USP www.revistas.usp.br/filosofiaantiga
J. anc. philos. (Engl. ed.), São Paulo, v.13, n.2. p. 109-145, 2019.

DOI: http://dx.doi.org/10.11606/issn.1981-9471.v13i2p109-145

ganho pecuniário indevido. ${ }^{7}$ Parece, assim, que a vantagem buscada pelo agente injusto nas suas ações tem, se não sempre, ao menos com frequência, natureza pecuniária. $\mathrm{O}$ exemplo de adultério em P2[6] parece centrado na busca de um proveito financeiro: apesar da ausência de detalhes na descrição da ação, é possível que ele se refira a ocorrências como o envolvimento de um homem com a esposa alheia motivado por recompensa pecuniária - daí que se diga que tal homem não é intemperante, mas sim ganancioso. ${ }^{8}$

Há, por fim, um terceiro passo na exposição da Justiça Parcial. Uma vez estabelecida a existência de um domínio específico de ações no qual essa virtude é engendrada e atualizada i.e., atos de justiça que não se sobrepõem aos atos de outras virtudes parciais - bem como a existência de motivação específica distinta daquela que conduz aos atos de justiça e injustiça gerais - i.e., a busca do proveito -, Aristóteles reaproxima em P3 a justiça parcial e a justiça geral, bem como os seus dois vícios correlatos. A distinção entre as duas modalidades de justiça e a sua reaproximação envolvem questões que fogem ao objeto desse artigo: por um lado, a acusação da homonímia feita logo no início do livro V (1129a26-1129b1), a partir da qual se estabelece que não há uma, mas duas virtudes chamadas de justiça; por outro, a afirmação de que há também sinonímia entre essas duas virtudes, que parecem pertencer a um mesmo gênero. De todo modo, P3 é um texto relevante para o ponto aqui discutido porque acrescenta informações importantes na caracterização da virtude da Justiça Parcial. Eis o texto, que em grego corresponde a um único período, mas que foi quebrado em 4 para facilitar a exposição e o comentário (1130a32-b5):

P3

[8] Assim, é manifesto que existe uma certa injustiça além da injustiça total, uma outra, parcial. [9] Ela é sinônima, porque a definição está no mesmo gênero: ambas, pois, possuem a capacidade no que é voltado a outrem. [10] Uma diz respeito a honra, às riquezas e à segurança, ou algum nome único que nós tivéssemos para incluir todas essas coisas, e decorre do prazer advindo do proveito indevido. [11] Já a outra diz respeito a todas as coisas de quantas se ocupa o homem excelente".

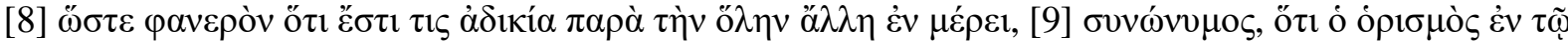

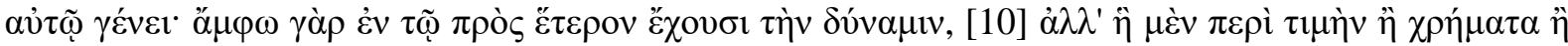

\footnotetext{
${ }^{7}$ Beekes, R.S.P. Etymological Dictionary of Greek. Two Volumes. (Leiden: Brill, 2010 (2009, p.363),

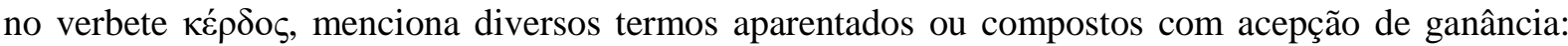

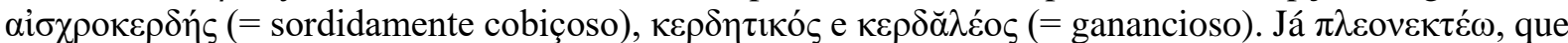
aparece como um composto no verbete $\pi \lambda \varepsilon^{i} \omega v$ (p.1.206), tem, além dessa acepção de ganância, uma

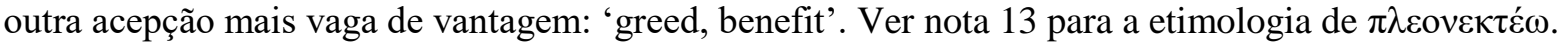

${ }^{8}$ Gauthier \& Jolif (2002, p.345): “[...] de même qu'il existe un acte précis, - à savoir, commettre un adultère, - qui renvoie au vice particulier qu'est l'intempérance, de même, dans le cas de l'injustice particulière, le langage a désigné le type d'acte qui en est la marque : agir pour amour du gain,

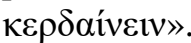




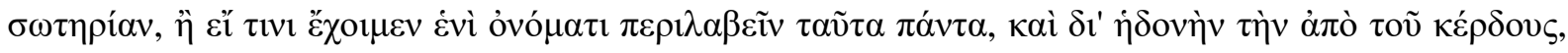

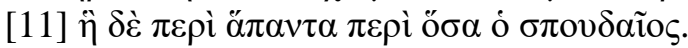

Enquanto [8] repete a conclusão de que existe uma outra virtude da justiça para além da geral, [9] reagrupa as duas virtudes como sendo sinônimas. Ambas, em tradução literal,

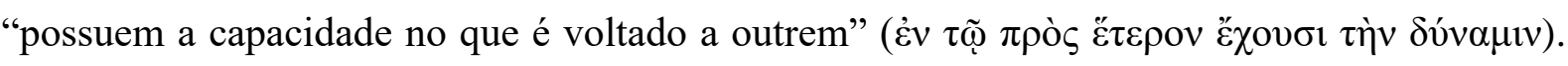
Em que consiste esse atributo comum às duas modalidades de justiça não é de modo algum evidente, e eu retomo o seu exame adiante. $\mathrm{O}$ fato é que, tendo enunciado aquilo que é comum à justiça parcial e à justiça geral, Aristóteles repisa a separação que buscara ao longo de P1 e P2. Cada uma das duas virtudes (e seu vício oposto) possui um âmbito de ação diferente. Em P3[10] nós nos deparamos com mais uma formulação do âmbito das ações da justiça parcial e da ganância: circunstâncias envolvendo bens (honra, segurança, riquezas) que ensejam a possibilidade de um proveito indevido que é prazeroso ao homem ganancioso. Aqui nós encontramos a única referência ao prazer na exposição da justiça parcial: o homem injusto age

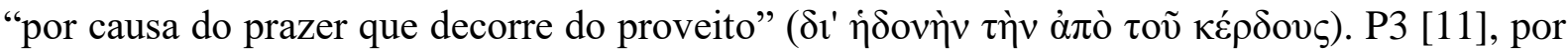
fim, reafirma a completude da justiça e da injustiça gerais ao afirmar que essas disposições dizem respeito a tudo de quanto se ocupa o homem excelente.

Ao final da sequência P1-P2-P3, pode-se dizer que, muito embora a justiça parcial tenha sido claramente delineada como sendo uma virtude distinta da justiça geral, nossa compreensão dela é ainda muito vaga. Inexiste em sua descrição uma referência clara à emoção que acomete tanto o homem justo quanto o ganancioso em suas práticas, e a referência ao prazer que acompanharia essa emoção é apenas uma menção. ${ }^{9}$ Mesmo o ato típico da justiça parcial está descrito na passagem de modo vago. Sabemos, por ora, que as ações de justiça parcial dizem respeito a certas relações humanas, como sugere a expressão ‘com vistas ao outro' ( $\pi \rho$ ò

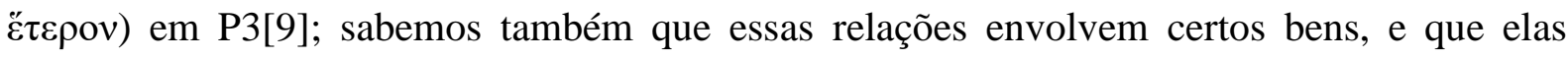
ensejam a oportunidade do proveito indevido aos gananciosos, que são aqueles homens que tiram vantagem nessas relações. No restante do segundo capítulo do livro V nós encontramos algumas repetições do que foi dito em P1-P2-P3, e depois o texto passa a tratar das instituições de justiça. Em razão dessa vagueza, a obtenção de uma caracterização mais completa da virtude da justiça parcial e do vício da ganância requer o recurso a outras passagens do livro V, que não

\footnotetext{
${ }^{9}$ A afirmação de que o prazer extraído seja do ato justo, seja do ato ganancioso, está baseada na tese exposta no livro II da Ética a Nicômaco, segundo a qual os prazeres e dores sentidos pelos agentes acompanham as emoções que os acometem. Ver em especial 1104a33-b11.
} 
tratam propriamente de virtude e de vício, mas que contêm informações hábeis a aprimorar nossa compreensão da conduta moral do homem justo e do ganancioso.

\section{A natureza interpessoal da conduta justa e da conduta gananciosa}

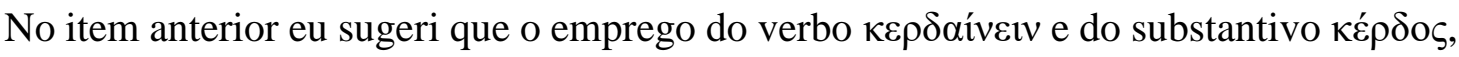

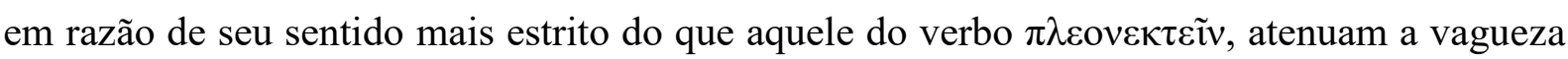
da exposição da justiça e da ganância em 1130a14-b5, i.e., em P1-P2-P3. O contexto pecuniário

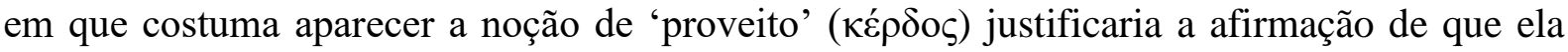

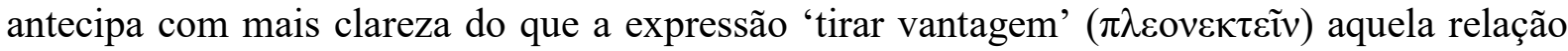
frequente entre justiça e riqueza, tão manifesta nas exposições das instituições de justiça por Aristóteles, em particular as distribuições e as trocas comerciais. ${ }^{10}$ A passagem que encerra o segundo capítulo do livro V, 1130b30-1131a10, onde as três modalidades institucionais de justiça parcial são distinguidas, atesta a relevância do dinheiro nas práticas da justiça e da ganância. Assim, uma dessas modalidades de relação, chamada de 'justo distributivo', conta, entre os exemplos de bens que são repartíveis entre concidadãos, as riquezas ( $\chi \rho \eta \mu \alpha ́ \tau \omega v-$ 1130b30-33). Já os exemplos de uma segunda modalidade de relação, as transações voluntárias, têm todos natureza pecuniária: "venda, compra, empréstimo, caução, arrendamento, depósito e

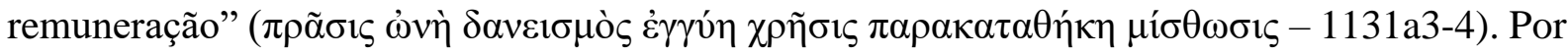
fim, a terceira modalidade de relação de justiça - as transações involuntárias, i.e., os crimes conta entre suas práticas (1131a5-9) diversos exemplos de crimes cujo cerne é a subtração ou

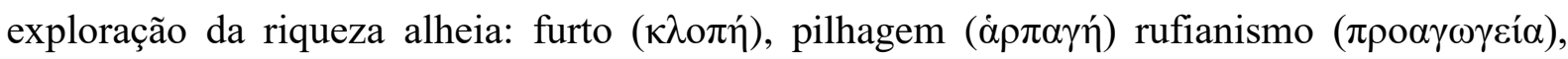

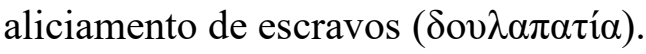

Seria, porém, um equívoco, reduzir a acepção de 'proveito' no livro V da Ética a Nicômaco a essa acepção pecuniária usual. A mesma passagem que expõe as três modalidades institucionais da justiça parcial menciona relações humanas que não envolvem riquezas. Por exemplo, dentre os bens passíveis de distribuição entre concidadãos está a honra ( $\tau \mu \eta \dot{)})$, possivelmente significando aqui os encargos públicos, uma honraria almejada entre os gregos

\footnotetext{
${ }^{10}$ Além da menção das riquezas enquanto bens distribuíveis entre cidadãos em 1130b30-33, e dos crimes contra o patrimônio listados em 1131a5-9, encontramos em 1133a19-31 a discussão das trocas voluntárias de bens, onde avulta uma breve teoria da moeda.
} 
Journal of Ancient Philosophy ISSN 1981-9471 - FFLCH/USP www.revistas.usp.br/filosofiaantiga
J. anc. philos. (Engl. ed.), São Paulo, v.13, n.2. p. 109-145, 2019.

DOI: http://dx.doi.org/10.11606/issn.1981-9471.v13i2p109-145

antigos. ${ }^{11}$ Assim, ao tratar em detalhe do 'justo distributivo' no capítulo 3 do livro V, Aristóteles se concentra exclusivamente na distribuição do poder político (1131a15-29), deixando de lado

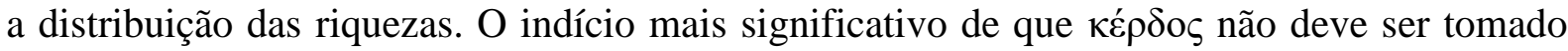
apenas na acepção mais estrita, porém, é a lista dos crimes em 1131a5-9. A maior parte das práticas criminosas ali mencionada não tem por objeto quaisquer riquezas, mas diz antes respeito a bens como a integridade física - agressão ( $\alpha i \kappa i ́ \alpha)$, cárcere ( $\delta \varepsilon \sigma \mu o ́ \varsigma)$, mutilação

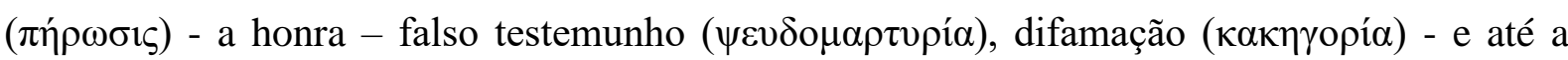
própria vida - homicídio ( $\theta \alpha ́ v \alpha \tau o \varsigma)$, envenenamento ( $(\alpha \rho \mu \alpha \kappa \varepsilon i ́ \alpha)$. Por essa razão, ao expor em detalhe o 'justo corretivo' no capítulo 4 do livro V, Aristóteles reconhece que o uso do termo

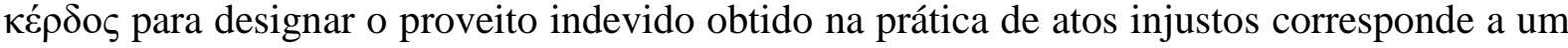
uso que não é restrito; 'proveito' designa, nesse caso, um excesso que é angariado pelo agente injusto no próprio ato de submeter sua vítima ao padecimento do crime cometido (1132a1014). ${ }^{12}$

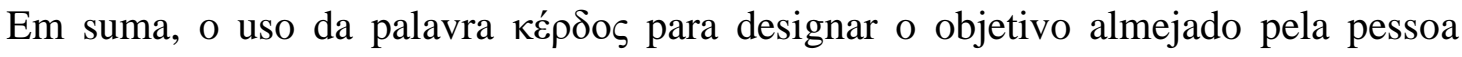
gananciosa parece indicar a importância do dinheiro como bem proeminente nas relações de justiça, ou ao menos o bem mais frequentemente envolvido nas interações humanas que pertencem à esfera da justiça. No entanto, a qualificação que Aristóteles se vê forçado a fazer para aplicar essa palavra a atos injustos que não possuem natureza pecuniária indica claramente que o domínio dos atos de justiça e injustiça não deve ser circunscrito às relações envolvendo dinheiro. A conduta justa e a conduta injusta dizem respeito a relações humanas que envolvem outros bens.

\footnotetext{
${ }^{11}$ Para esse sentido de $\tau \mu \eta \eta ́$, ver Beekes (2010, p.1485) e Chantraine, P. Dictionnaire Étymologique de la Langue Grecque. Histoire des Mots. Avec un Supplément sous la direction de Alain Blanc, Charles de Lamberterie, Jean-Louis Perpillou. (Paris : Klincksieck, 1999, p.1119). O próprio Aristóteles, ao exemplificar a distribuição no terceiro capítulo do livro V (1131a15-29), discute a distribuição do encargo público. Essas considerações justificam a observação feita por Jackson (1879, p.75-76): "Here

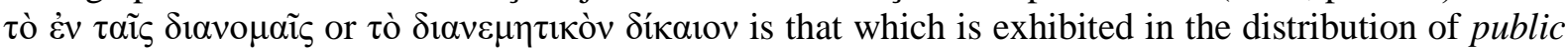
position, property and advantages...".

12 Zingano (2017, p.190) e Gauthier \& Jolif (2002, p.362-363) comentam o uso extensivo de proveito/ganho e perda em determinados exemplos da justiça corretiva. $\mathrm{O}$ comentário mais claro e

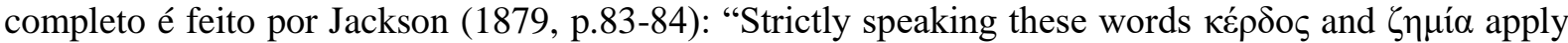
only to cases in which the one seeks the restitution of property wrongfully appropriated by the other: but they may be used in an extended sense; for example, the satisfaction which $A$ derives from striking

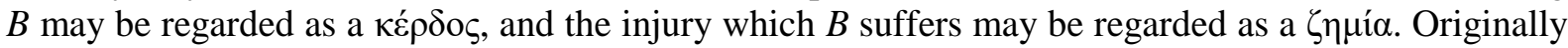
however, as we are told in $\S 13$, these words applied to neither of these cases, but only to the profit and loss of commerce and of other transactions not interfered by law".
} 
A passagem 1130b30-1131a10, nesse sentido, é muito elucidativa. Embora não haja ali

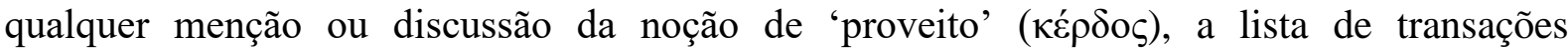
pecuniárias, crimes e bens passíveis de distribuição torna a exposição das condutas justa e injusta feita em P1-P2-P3 mais palpável e menos vaga, ao menos de dois modos. Em primeiro lugar, há a explicitação das circunstâncias daquilo que P3 [9] chama de capacidade de agir c̉v

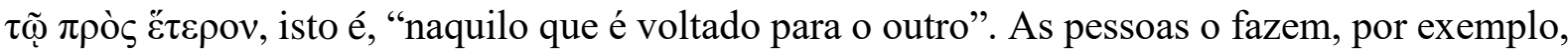
na condição de concidadãos que estão em relação uns com os outros nas ocasiões em que determinados tipos de bens lhes são aportados pelos legisladores (1130b30-33; ver também 1131a15-29); também na medida em que interagem voluntariamente em relações pecuniárias, comprando, vendendo, emprestando recursos, pagando e recebendo remunerações etc. (1131a15; ver também 1132b31-34); por fim, na medida em que eventualmente são envolvidos em relações involuntárias, tornando-se vítimas de práticas criminosas alheias (1131a5-9; ver também 1131b32-1132a10) ou atuam como juízes na punição dos criminosos (1132a21-32). Há, em outros termos, uma natureza interpessoal no exercício tanto da virtude da justiça parcial quanto do vício da ganância. Em segundo lugar, a menção dos crimes e das transações elucida os bens em relação aos quais o homem ganancioso pode almejar tirar vantagem ou obter proveito indevido. Trata-se com frequência do dinheiro, mas não necessariamente: bens como a integridade física, a honra e a vida também podem tornar-se alvos do ganancioso. Esses dois aspectos das ações justas e injustas - sua natureza interpessoal e a variedade dos bens envolvidos - são relevantes no exame que eu faço adiante do prazer envolvido em tais ações.

Por ora eu gostaria de expandir a discussão sobre a natureza interpessoal da prática da justiça e da injustiça. Os diferentes contextos nos quais os atos justos e gananciosos têm lugar - distribuições, transações e crimes - sugerem que esses atos possuem uma estrutura relacional ou de interação. As próprias noções de igualdade e desigualdade designam certas relações humanas, de sorte que atos justos e injustos sempre envolvem pelo menos duas pessoas, que se encontram em igualdade ou desigualdade uma para com a outra. Isso significa que a própria noção de 'proveito indevido' ( $\varepsilon \dot{\rho} \rho \delta o \varsigma)$ deve ser compreendida enquanto inserida em uma estrutura relacional: a obtenção de proveito indevido por parte do homem ganancioso impacta na situação de outras pessoas, aquelas que são de algum modo lesadas como consequência do proveito angariado por aquele homem. Em outras palavras, a todo ato ganancioso, enquanto ato 


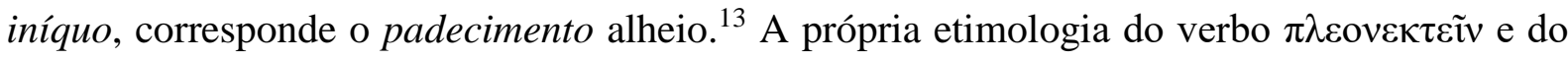

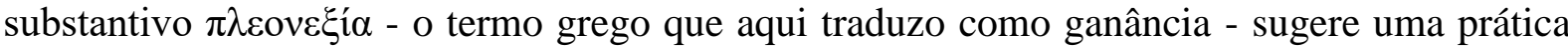
viciosa que necessariamente impacta sobre outrem. Ambos são compostos pelo comparativo

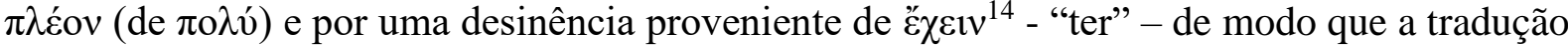

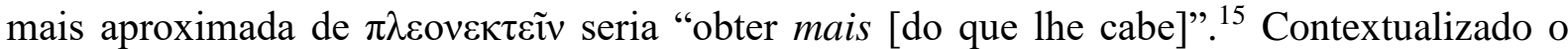
verbo na relação de desigualdade, o grau comparativo do adjetivo pressupõe a existência de um "menos [do que lhe cabe]", que resta para o outro polo da relação.

Essa situação é particularmente visível nos casos de justiça corretiva: os tribunais julgam circunstâncias nas quais uma parte obteve um proveito indevido ( $\kappa \varepsilon ́ p \delta o \varsigma)$ que é correlato ao dano ( $\beta \lambda \alpha \dot{\beta} \eta)$ sofrido pela outra parte (1131b32-1132a19). A natureza interpessoal ou $\pi \rho o ̀ \varsigma$

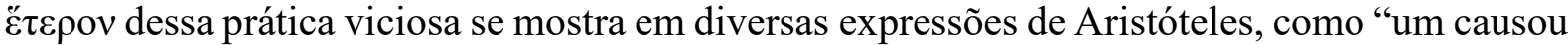

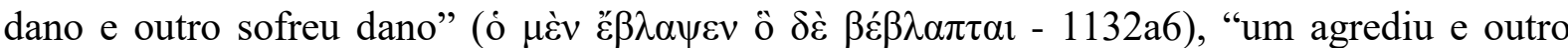

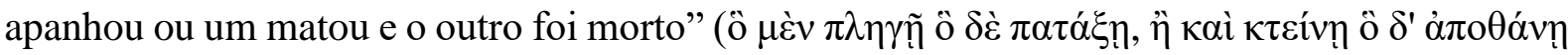

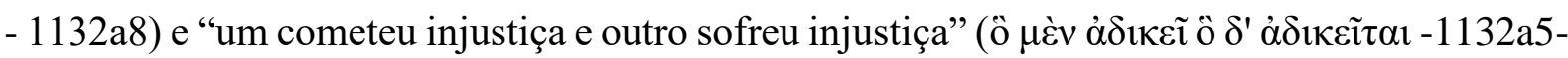
6). Todas essas frases são modos diferentes de enunciar que a ocorrência de atos de injustiça

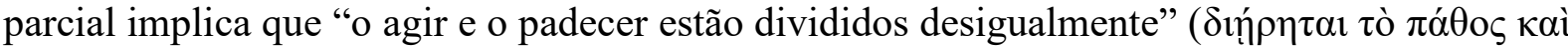

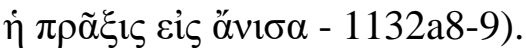

A descrição do ponto médio e de seus desvios a partir de 1133 b29 é igualmente sugestiva da natureza interpessoal do exercício tanto da justiça parcial quanto da ganância. Essa passagem aparece no ponto em que Aristóteles encerra a longa exposição dos tipos de relação de igualdade: justiça distributiva, corretiva e recíproca. Tal contexto justifica que a mediania da justiça seja ali descrita como uma relação ou interação equilibrada entre (pelo menos) duas partes, ao passo que a injustiça apareça como uma relação ou interação desequilibrada, i.e., que contém excesso em um polo e deficiência em outro. Trata-se de uma caracterização atípica da tríade "ponto médio-excesso-deficiência", pois o procedimento usual de Aristóteles é atribuir cada um dos três componentes da tríade a uma disposição do caráter: a virtude

\footnotetext{
${ }^{13}$ Por essa razão, ao comentar a sinonímia que subsiste entre injustiça geral e injustiça parcial, Jackson

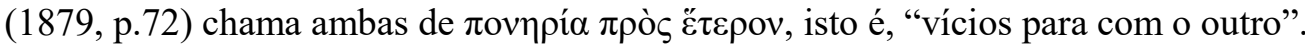

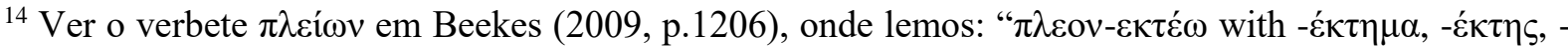

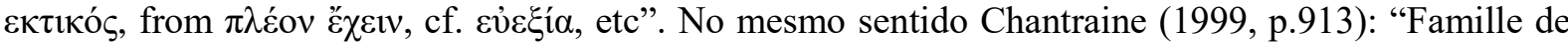

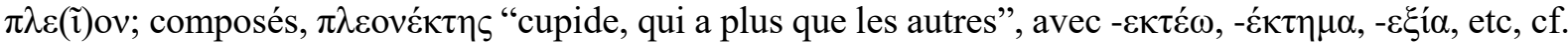
s.u. $\check{\chi} \chi \omega \ldots$ ».

${ }^{15}$ Lucas Angioni (Unicamp) chamou minha atenção para a importância do grau comparativo de $\pi$ o $\lambda v$

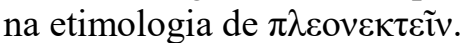


corresponde ao ponto médio, o excesso a um vício e a deficiência a outro vício. ${ }^{16}$ No caso da justiça parcial, ao contrário, nós observamos que a virtude é oposta a apenas um vício, a injustiça (parcial), que corresponde aos dois desvios em relação ao ponto médio, tanto ao excesso quanto à deficiência. A importância desse texto (1133b29-1134a10), que chamo de P4, justifica sua citação:

\section{P4}

[...] é manifesto que a prática da justiça é um ponto médio entre agir injustamente e ser injustiçado: pois o primeiro é ter mais do que lhe cabe e o segundo é ter menos do que lhe cabe. A justiça é um certo ponto médio, não do mesmo modo que as demais virtudes, mas porque ela é do ponto médio; a injustiça, por sua vez, é dos extremos. E a justiça é a disposição segundo a qual o justo é dito praticante por escolha do ato justo, isto é, ele distribui bens entre si mesmo e um outro, ou entre dois outros, não de modo tal que ele venha a obter para si mesmo mais do que é digno de escolha e menos para o seu próximo, fazendo o contrário quanto ao que é oneroso [...] do ato de injustiça, a deficiência é ser injustiçado e o excesso é cometer a injustiça.

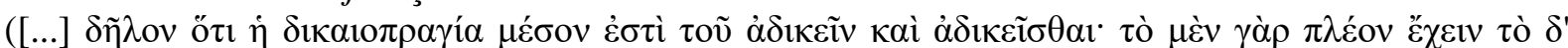

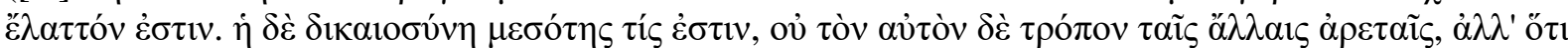

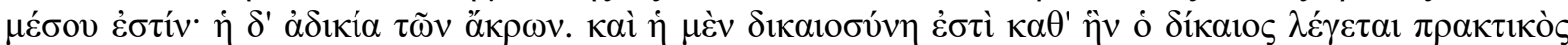

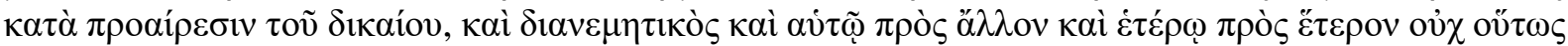

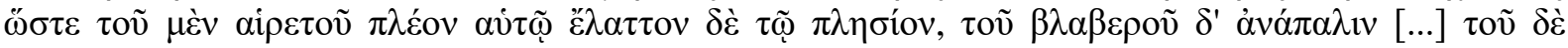

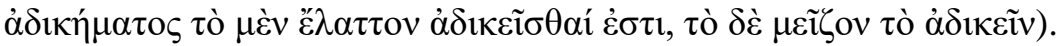

No primeiro trecho cuja tradução encontra-se em itálico nós observamos que a prática da justiça ( $\delta 1 \kappa \alpha \iota \pi \rho \alpha \gamma i ́ \alpha)$ é apresentada como ponto médio, ao passo que os excessos são, de

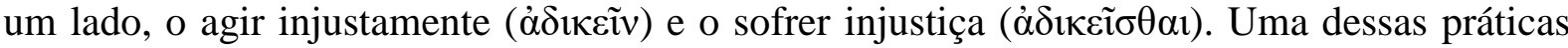

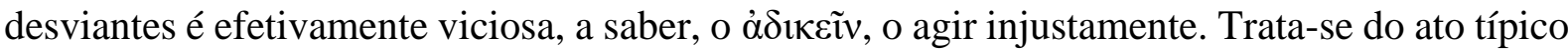
do agente ganancioso. Mas o outro desvio - o sofrer injustiça - não é vicioso e não é sequer uma prática, mas antes um padecimento. Na sequência, Aristóteles menciona a mediania da virtude da justiça e atribui os dois polos desviantes à injustiça. $\mathrm{O}$ vício da injustiça, nos diz o segundo trecho em itálico, é “dos extremos” ( $\tau \tilde{\omega} v$ ók $\rho \omega v)$.

Essa atribuição é importante não somente pela singularidade da injustiça ser um vício relacionado aos dois desvios do ponto médio, mas sobretudo porque o contexto da passagem sugere que os dois desvios são dois aspectos distintos de um mesmo ato injusto. Vejamos: a atribuição do padecimento 'sofrer injustiça' à prática da injustiça não significa, por óbvio, que esse padecimento seja um ato injusto, e que a pessoa que sofre uma injustiça seja alguém

\footnotetext{
${ }^{16}$ Não há espaço aqui para uma discussão geral da mediania na ética aristotélica e de suas conhecidas dificuldades. Ver Ethica Nicomachea 1106b14-1107a8, onde Aristóteles trata do tema como elemento da caracterização da virtude do caráter em geral, e 1107a28-1108b10, onde essa caracterização é aplicada às mais variadas virtudes e vícios.
} 
Journal of Ancient Philosophy ISSN 1981-9471 - FFLCH/USP www.revistas.usp.br/filosofiaantiga
J. anc. philos. (Engl. ed.), São Paulo, v.13, n.2. p. 109-145, 2019.

DOI: http://dx.doi.org/10.11606/issn.1981-9471.v13i2p109-145

injusto. ${ }^{17}$ Porém, não há dúvida de que a passagem caracteriza esse padecimento como a deficiência em relação ao ponto médio: sofrer injustiça equivale a "ter menos" ( $\tau$ ò $\delta$ ' غ̌ $\lambda \alpha \tau \tau o ́ v$ $\dot{\varepsilon} \sigma \tau \imath v)$, e ambos os desvios são característicos da prática injusta. Como entender, então, essa atribuição? Quando nós temos em mente a natureza interpessoal das práticas justas e injustas, torna-se então visível que o padecimento da injustiça é atribuído à prática injusta na qualidade de consequência inseparável da própria prática injusta ${ }^{18}$ : na medida em que a pessoa gananciosa angaria mais do que lhe caberia, isto é, desvia a relação em direção ao excesso, ocorre necessariamente também o desvio em direção à deficiência, que é o padecimento sofrido pela outra parte da relação. ${ }^{19}$ Portanto, a parelha "agir injustamente e ser injustiçado" - $\dot{\alpha} \delta 1 \kappa \varepsilon i ̃ v$

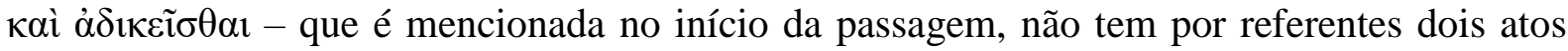
distintos, dois exemplos avulsos de ações que se opõem à ação justa. Essa parelha designa dois aspectos de uma mesma interação: o fato de que alguém pratica a injustiça e outra pessoa

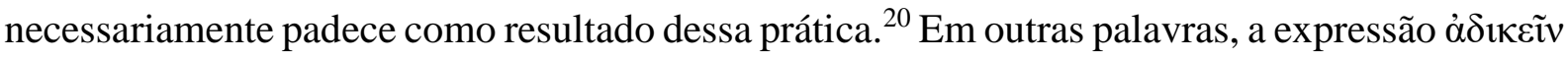

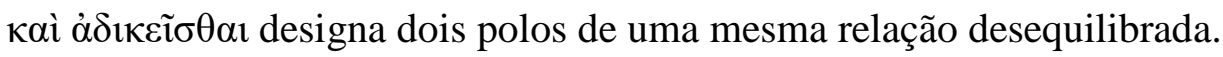
17 "Porque a justiça é uma relação com outrem, seu contrário, a injustiça, é como uma estrada por onde
se vai e volta: é simultaneamente o ato de cometer a injustiça e o de sofrer injustiça, mas sofrer injustiça
é o reflexo do ato do outro, não a aquiescência da parte de quem a sofre de ter menos. Alguém pode não
reivindicar seus direitos por medo de sofrer ainda mais represálias, mas isso provém de considerações
prudenciais, a respeito das quais a pessoa pode estar certa ou errada, não de alguma suposta falta de
justiça ou aquiescência à injustiça" (Zingano, 2017, p.217).

${ }^{18}$ Ver a observação de Kraut (2002, p.158-159): “[...] unjust acts are Always both excessive and deficient. That is so because their injustice consists in a disproportionate relation between two or more people: someone gets too little precisely because someone else gets too much. The excess cannot exist unless the deficiency is present at the same time".

${ }^{19}$ Ver, nesse sentido, os exemplos didáticos de Young, C.M. "Aristotle's Justice” in Kraut, R. (org.). The Blackwell Guide to Aristotle's Nicomachean Ethics. (Blackwell Publishing, 2006, p.185-186) para o ponto médio nos dois casos paradigmáticos de justiça parcial, a distribuição e a correção.

${ }^{20}$ Zingano (2017, p.217-219) cataloga as diferentes tentativas de interpretar a peculiaridade da mediania da justiça, onde avultam três interpretações: (1) a justiça é mediania peculiar porque se opõe apenas a um vício e não a dois, como as outras virtudes do caráter; (2) a justiça é uma mediania peculiar porque a ação justa (assim como a injusta) é relacional, envolvendo o agente e o paciente; (3) a justiça é uma mediania peculiar porque possui um caráter matemático mais marcado e rigoroso que o das outras virtudes. Zingano, embora reconhecendo o mérito de (1) e (2), opta por (3). A minha interpretação da passagem mixa (1) e (2) de um modo que é previsto pelo próprio Zingano: é (2), isto é, o caráter relacional do ato justo e do injusto, que explica (1), isto é, que a justiça se oponha somente a um vício e não a dois (como o ato injusto produz ganho ao agente e perda ao paciente, a injustiça corresponde tanto ao excesso quanto à deficiência com relação ao ponto-médio que é a justiça). Ver também, nesse sentido, Gauthier \& Jolif (2002, p.409): "Nous comprenons plutôt que l'injustice est simultanément excès et défaut : un acte d'injustice n'est pas seulement fait, il est aussi subi, et il entraine à la fois le plus et le moins. C'est surtout en se plaçant à ce point de vue qu'on comprend au mieux pourquoi Aristote a fini 
Journal of Ancient Philosophy ISSN 1981-9471 - FFLCH/USP www.revistas.usp.br/filosofiaantiga
J. anc. philos. (Engl. ed.), São Paulo, v.13, n.2. p. 109-145, 2019.

DOI: http://dx.doi.org/10.11606/issn.1981-9471.v13i2p109-145

O restante da passagem sugere que essa é a interpretação correta. Logo após a atribuição dos dois desvios do ponto médio à injustiça, Aristóteles passa a descrever (ou recapitular) a prática típica da pessoa justa, acrescentando uma observação importante sobre aquilo que ela não faz - que é precisamente aquilo que a pessoa gananciosa faz. Trata-se do terceiro trecho cuja tradução eu pus em itálico: o agente injusto age de modo a obter mais para si mesmo daquilo que é digno de escolha e menos para o seu próximo (

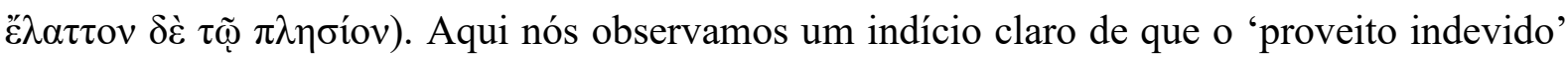
que a pessoa gananciosa obtém em uma interação está necessariamente relacionado a um dano que ela causa para outra pessoa. A busca do excesso por parte da pessoa injusta termina por causar a deficiência para outra pessoa. Por fim, a última observação que se encontra em itálico na passagem expõe de modo explícito a correlação entre excesso e deficiência na prática da injustiça: 'agir injustamente' e 'sofrer injustiça' são unificados enquanto partes do 'ato de

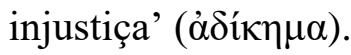

A passagem sobre o ponto médio e seus desvios é, em razão dessas considerações, essencial para a caracterização do proveito indevido ( $\kappa \dot{\varepsilon} \rho \delta \circ \varsigma$ ) almejado pelo agente injusto. Enquanto resultado do ato injusto, o proveito indevido seria uma quota excessiva de um bem que é obtida no contexto de uma interação e que por isso implica um dano que é causado a outra

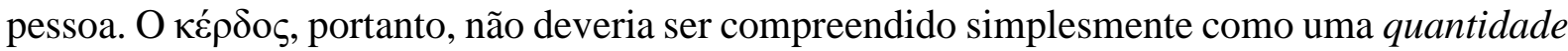
de um determinado bem, mas como uma quantidade que é obtida às expensas de outrem. ${ }^{21}$

Em minha tentativa de explicar a natureza interpessoal dos atos justos e injustos eu frequentemente falei em relação ou interação. É possível enxergar uma diferença de grau nesses dois termos. Enquanto interação designa uma aproximação efetiva entre pelos menos dois

par admettre que la justice n'est pas moyenne entre deux vices : un seul et même acte d'injustice suffit à faire apparaître les deux extrêmes ».

${ }^{21}$ Young (2006, p.183), ao comentar a semelhança e a diferença entre a justiça e as demais virtudes que se relacionam com bens externos, faz a seguinte observação no sentido da ênfase peculiar da justiça no elemento interpessoal da conduta: "Presumably, particular justice has a diferente concern with honor, wealth, and safety from that of the other virtues. Aristotle makes no effort to tell us what the difference might be, but perhaps his idea is that, for example, my cheating on my taxes shows both something about my attitude toward wealth - a concern of liberality - and something about my attitude toward those other citizens who must shoulder the burden I have shirked - a concern of justice". No mesmo

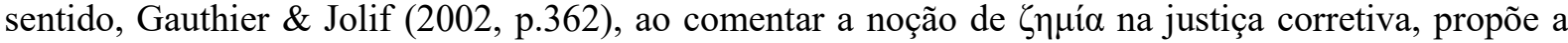
tradução "perda" ao invés de "penalidade", pois a perda sofrida por quem padece o ato injusto

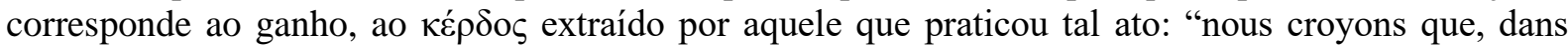
l'ensemble de ce passage, zémia et kerdos désignent la partie perdante et la partie gagnante, tout autant que la perte et le gain". 
agentes, relação poderia indicar uma correlação entre duas pessoas que não estão necessariamente interagindo. As trocas comercias e os crimes seriam formas de interação: dois agentes aproximam-se mutuamente com vistas a realizar a compra e venda de um determinado produto; ou um agente vitima um outro por meio de sua conduta criminosa, forçando uma interação que é involuntária por parte da vítima. Já distribuição de bens parece apenas estabelecer uma relação entre diferentes pessoas, sem que elas necessariamente interajam. Tomemos o exemplo de um regime oligárquico, que propicie maior participação política para pessoa ricas e menor participação política para pessoas pobres, de sorte que as próprias leis da comunidade passem a refletir a supremacia de seus cidadãos ricos. Nessas circunstâncias, dois concidadãos - um rico e outro pobre - estão em uma relação caracterizada pela proporção entre suas diversas quotas de poder e o critério de distribuição desse poder: o cidadão rico, por possuir mais riqueza, possuirá também mais poder político, ao passo que o cidadão pobre, possuidor de menos riqueza, possuirá por isso uma quota menor do poder político. Tal correlação não implica, por óbvio, qualquer interação entre esses cidadãos. Dois cidadãos quaisquer, que sequer conheçam um ao outro, estarão correlacionados do mesmo modo. A proporção que caracteriza a distribuição de poder é também interpessoal na medida em que relaciona diferentes pessoas segundo seus atributos pessoais correspondam em maior ou menor grau ao critério de distribuição. Apenas ocorre que essa relação não tem a natureza interativa das transações voluntárias e involuntárias.

No entanto, o elemento de interação não está de todo ausente nas distribuições. A natureza conflitiva da questão distributiva sugere que o elemento interativo permanece latente quando o regime político se encontra estável, mas vem à tona em situações de crise. Ao descrever a distribuição de poder no livro V da Ética a Nicômaco, Aristóteles enfatiza as

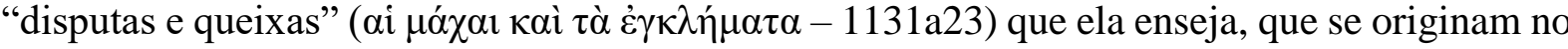
fato de que há desacordo generalizado quanto ao critério adequado para essa distribuição. "Os democratas consideram que se trata da liberdade, os oligarcas da riqueza, outros do bom nascimento, e os aristocratas da virtude" (1131a27-29). Nesse sentido, uma crise constitucional, quando mudanças significativas no regime se tornam iminentes, teria o condão de transformar as questões distributivas em interações conflituosas. Um exemplo interessante desse fenômeno encontra-se na Constituição dos Atenienses. Aristóteles narra a tentativa de Sólon em instituir a $\sigma \varepsilon 1 \sigma \alpha ́ \chi \chi \theta \varepsilon 1 \alpha$, o cancelamento de todas as dívidas dos camponeses atenienses, que naquele tempo tornavam-nos suscetíveis à escravização. A medida enfrentou a oposição não somente 
da elite proprietária de terras, mas também dos próprios camponeses. Enquanto os primeiros desejavam manter o velho sistema de arrendamento no qual a falta de pagamento tornava os camponeses sujeitos à escravidão, os últimos desejavam uma redistribuição em larga escala das terras em Atenas, e consideravam por isso que o cancelamento das dívidas era medida insuficiente (II.2-3; VI.1-4; XI.2; XII.4).

Assim, o potencial conflitivo que subjaz questões distributivas permite uma aproximação do 'justo distributivo’ com as demais práticas institucionais da justiça parcial, o 'justo corretivo' e o 'justo recíproco': todas elas, de modo explícito ou latente, são circunstâncias de ação na qual pessoas interagem tendo em vista determinados bens. Daí a observação que fiz há pouco a respeito do proveito indevido almejado pelo homem ganancioso - não se trata somente da quota de um bem, mas de uma quota que é buscada em detrimento das demais pessoas envolvidas na relação ou interação. O desejo por essa quota excessiva pode se manifestar não somente na prática de crimes contra o patrimônio ou a integridade física alheia, na tentativa de fraudar transações comerciais em proveito próprio, mas também, como atesta o exemplo da $\sigma \varepsilon 1 \sigma \alpha ́ \chi \theta \varepsilon ı \alpha$, na recusa de uma medida conciliatória como o cancelamento das dívidas, por parte dos camponeses porque desejam obter as terras dos oligarcas, e por parte desses porque eles desejam apossar-se da liberdade dos camponeses.

Para encerrar esse tópico, vale a pena tecer mais algumas considerações a respeito dos bens envolvidos nas interações justas e injustas, bens que ensejam a possibilidade do proveito indevido. Eles devem ser sempre contextualizados nessas interações para que se compreenda melhor a conduta moral dos agentes justos e injustos. A caracterização do domínio das ações da justiça parcial em P3 [10] menciona uma lista desses bens, certamente não-exaustiva ${ }^{22}$, e acrescenta uma observação que pode parecer curiosa: Aristóteles parece afirmar que seria desejável que houvesse um nome comum para designar todos esses bens, mas que tal nome não existe. A observação é curiosa porque o próprio Aristóteles se refere em outros contextos aos

\footnotetext{
${ }^{22}$ Young (2006, p.183) defende posição contrária à minha, isto é, que a enumeração dos bens em 1130b2 (ou P3[10]) é exaustiva, e representa uma delimitação face à lista ampla de bens externos apresentadas no livro I da Ética a Nicômaco: "A list of external goods that Aristotloe gives at $N E$ I.8.1099a31-b8 includes friends, wealth, political power, good birth, satisfactory children, and personal beauty. Plainly justice and Injustice will not have to do with all of these, and at NE V.21130b2, Aristotle accordingly narrows the list of external goods with which justice and injustice are concerned to honor, wealth and safety. These all seem to be things that one might want more than one's fair share of, i.e., things that one might be greedy for" (itálicos meus). No próximo tópico, quando trato do prazer que caracteriza a virtude da justiça parcial e o vício da ganância, eu mostro como essa leitura restritiva dos bens externos é incompatível com elementos importantes do tratamento desses temas por Aristóteles.
} 
bens tais como aqueles listados em P3 [10] - honra, riquezas, segurança - como "bens exteriores" ( $\tau \grave{\alpha} \dot{\alpha} \gamma \alpha \theta \grave{\alpha} \dot{\varepsilon} \kappa \tau o ́ \varsigma) .{ }^{23} \mathrm{E}$, de fato, bens como as riquezas e a honra são exteriores à alma dos agentes, donde se segue sua inconstância quando comparados às virtudes, os bens que inerem de modo constante na alma humana. ${ }^{24}$

Essa resistência em nomear os bens pertinentes à justiça parcial, no entanto, ecoa uma passagem que se encontra no início do livro V da Ética a Nicômaco. Trata-se da caracterização breve do vício da ganância em 1129b1-11. Diz-se ali que o vício oposto à justiça está estreitamente relacionado a uma urgência inadequada na aquisição de determinados bens pelos homens. Tais bens seriam sempre bons quando tomados em absoluto, mas não seriam

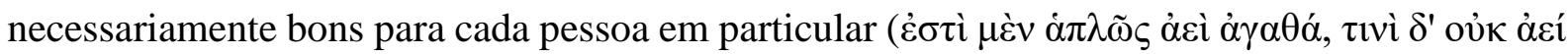
- 1129b3-4). Seria por isso recomendável que as pessoas desejassem não apenas possuir esses bens, que em si mesmos são bons, mas que também desejassem que esses bens sejam bons para elas (1129b4-6). O contexto da passagem 1129b1-11 não permite esclarecer o sentido dessa assertiva. Há, porém, algumas observações na Ética Eudêmia que são esclarecedoras: aquilo que faz com que certos bens, que em si mesmos são bons, sejam bons para alguém, é o bom caráter dessa pessoa; bens como a honra, a riqueza, força, fortuna e poder - todos bens exteriores à alma - são benéficos para homens bons, mas nocivos para homens perversos (1248b26-37). ${ }^{25}$ Em suma, bens exteriores são bons para pessoas virtuosas e nocivos para pessoas viciosas. De que modo exatamente os bens exteriores prejudicam homens perversos não é ali dito expressamente. Nós sabemos, porém, que muitos vícios do caráter são engendrados a partir de situações reiteradas de desejo e fruição inapropriada de bens exteriores: o anelo excessivo pela satisfação física, por exemplo, faz uma pessoa desenvolver disposição

\footnotetext{
${ }^{23}$ A distinção entre bens interiores (à alma) e bens exteriores é mencionada em Ethica Eudemia 1218b31-37 como tendo sua origem nos escritos exotéricos. Ao final do tratado, em 1248b26-1249a2, Aristóteles apresenta uma lista de bens exteriores, aos quais ele atribui uma bondade natural que pode, no entanto, se converter em nocividade por causa do caráter da pessoa que eventualmente possua tais bens.

${ }^{24}$ Sobre a inconstância da honra ver Ethica Nicomachea 1095b22-31, onde Aristóteles a descarta como cerne da vida política, substituindo-a precisamente pela virtude, cuja posse pelo agente é muito mais segura. Sobre o desvalor do dinheiro enquanto elemento da felicidade, ver 1096a6-7.

${ }^{25}$ A proximidade entre o conteúdo de Ethica Nicomachea 1129b1-11 e Ethica Eudemia 1248b26-37 tanto no que diz respeito aos exemplos de bens que são mencionados quanto na sua caracterização como potencialmente vantajosos ou nocivos - me parece justificar o entendimento unânime dos comentaristas do livro V da Ética a Nicômaco no sentido de que são os bens exteriores que Aristóteles atribui ao domínio da justiça e da ganância em 1129b1-11: Stewart (1892, p.387), Zingano (2017, p.161-162), Gauthier \& Jolif (2002, p.337), Jackson (1879, p.67).
} 
intemperante; o apego excessivo à própria riqueza torna alguém um avaro (1118b271119a5;1119b26-30).

Nesse sentido, a passagem a respeito da ganância em 1129b1-11 parece contextualizála em meio aos vícios que se consolidam no caráter dos agentes em função do apego e da fruição desregrada de bens externos. Ainda na Ética Eudêmia, Aristóteles atribui o anelo excessivo por bens externos à maioria dos homens: os bens externos "parecem ser intensamente disputados e

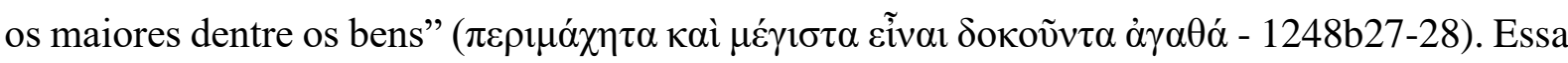

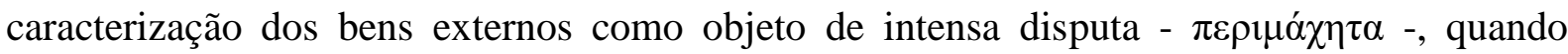
cotejada com as observações que eu fiz acima a respeito da natureza interpessoal das condutas justas e gananciosas, indica a situação fundamental na qual os atos de justiça parcial e de ganância têm lugar: subjacente às práticas institucionais das trocas comerciais, subjacente ao cometimento de crimes e à sua punição, subjacente à distribuição de bens entre concidadãos, existe uma comunhão desses bens com potencial de engendrar conflitos interpessoais agudos.

\section{O prazer experimentado nas interações do justo e do ganancioso}

Nas observações introdutórias eu afirmei que articular uma explicação do prazer e da emoção envolvidos no exercício das ações de justiça parcial e de ganância é uma tarefa mais difícil do que delinear a estrutura das condutas morais do agente justo e do ganancioso. A razão dessa dificuldade é a economia de palavras do texto ao tratar daquelas questões. Sobre o prazer nós encontramos apenas uma menção passageira, feita em P3 [10]: existe um certo prazer sentido pela pessoa gananciosa, que decorre do proveito indevido obtido através da sua conduta. Em P3 [9], por sua vez, está a expressão na qual eu entendo haver uma alusão à emoção envolvida nos atos de justiça e de ganância, a saber, a "capacidade naquilo que é para o outro".

Essas observações, embora constituam indícios textuais modestos, permitem uma afirmação inicial: na medida em que o prazer e a emoção porventura envolvidos nas práticas justas e gananciosas estão contextualizados na relação do agente com o outro e na possibilidade de angariar proveito indevido nessa relação, tal prazer e tal emoção estão diretamente relacionados à natureza interpessoal da conduta justa e da conduta gananciosa. Isso significa que a estrutura relacional dessas ações, exposta no tópico anterior, é o melhor ponto de partida para a reflexão sobre o prazer e a emoção envolvidos nas ações justas e gananciosas. $\mathrm{O}$ fato de que os indícios textuais sobre esse tema sejam modestos sugere cautela ao intérprete, no sentido 
Journal of Ancient Philosophy ISSN 1981-9471 - FFLCH/USP www.revistas.usp.br/filosofiaantiga
J. anc. philos. (Engl. ed.), São Paulo, v.13, n.2. p. 109-145, 2019.

DOI: http://dx.doi.org/10.11606/issn.1981-9471.v13i2p109-145

de que tal situação implica que quanto mais a interpretação avança, mais discutível ela se torna, e maior o risco de aventurar-se em conjeturas alheias ao pensamento de Aristóteles. Por outro lado, a necessidade de pensar a justiça parcial e a ganância enquanto virtude e vício do caráter, e, portanto, de contextualizar essas duas disposições no quadro geral da ética aristotélica, é um esforço interpretativo ao qual os estudiosos não podem se furtar. Se realizado com a cautela mencionada, esse esforço pode render bons frutos.

Prazer e desgosto, de um lado, e emoções, de outro, são realidades muito próximas para Aristóteles. No livro II da Ética a Nicômaco, onde se encontra o estudo das virtudes do caráter consideradas em geral, o filósofo afirma que os prazeres e desgostos experimentados pelos agentes acompanham as emoções que acometem esses mesmos agentes por ocasião da ação

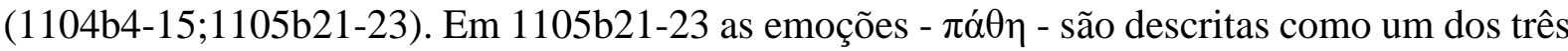
tipos de inerência da alma humana (os outros dois sendo as capacidades emotivas e as disposições). Aristóteles apresenta um catálogo de emoções e menciona o que parece ser uma característica comum a todas as emoções: "de modo geral [aquelas inerências da alma] às quais

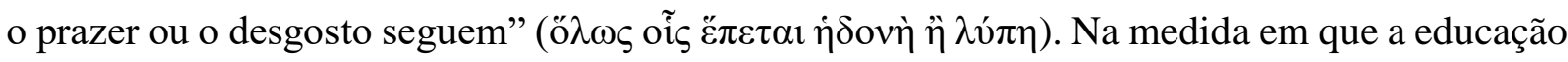
moral dos agentes visa desenvolver disposições virtuosas de caráter, que são disposições segundo as quais os agentes se portam bem face às emoçõe ${ }^{26}$, os prazeres e desgostos sentidos no exercício das ações, por acompanharem as emoções, constituem um indício do tipo de disposição que um determinado agente desenvolveu (ver em especial 1104b4-15). Por exemplo, se a participação em uma batalha é assaz desgostosa ao agente, isso é um indício de que ele não desenvolveu a virtude da coragem, mas sim a disposição viciosa da covardia, na qual o temor demasiado sentido pelo agente torna-lhe a luta desgostosa ${ }^{27}$; se a fruição exagerada de deleites físicos é prazerosa a alguém, isso é indício do desenvolvimento da disposição viciosa chamada

\footnotetext{
${ }^{26}$ Eis a caracterização das disposições logo após as emoções e as disposições no capítulo 5 do livro II da Ética a Nicômaco: "chamo de disposições aquelas [inerências da alma] segundo as quais nós nos portamos bem ou mal com relação às emoções, por exemplo, com relação ao irritar-se, se isso nos ocorre abrupta e facilmente, nós nos portamos mal, mas se nos ocorre medianamente, nos portamos bem. E de

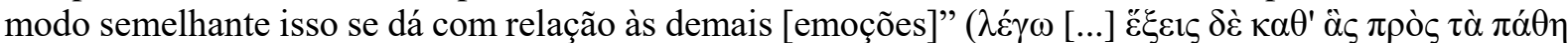

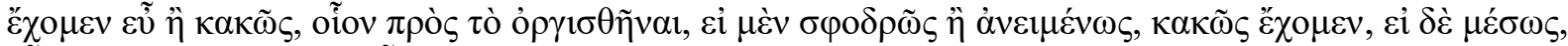

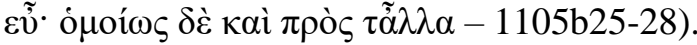

${ }^{27}$ Estou deixando de lado aqui e nos demais exemplos da passagem a sutileza que é a possibilidade de o agente não ter o vício da covardia, mas ser apenas um incontinente, isto é, alguém que sabe que deve lutar, mas teme demasiadamente a luta, ou sabe que deve evitar o excesso de deleites físicos, mas os aprecia em demasia. A discussão cuidadosa dessas questões foge ao tema do artigo.
} 
intemperança, na qual o apego demasiado a tais deleites os torna prazerosos ao agente e qualquer abstinência parece-lhe muito desgostosa.

Nesse sentido, a menção do prazer em P3 [10], breve porém inquestionável, permite uma conclusão inteiramente consistente com os ensinamentos de Aristóteles a respeito das virtudes do caráter: sendo a ganância um vício do caráter, portanto uma disposição segundo a qual o agente se porta mal com relação a alguma emoção ${ }^{28}$, o prazer que ele sente ao angariar proveitos indevidos em suas interações deve acompanhar precisamente essa emoção, sendo por isso um indício de que o agente desenvolveu o vício do caráter chamado de ganância ( $\left.\pi \lambda \varepsilon \operatorname{cov}_{\varepsilon} \xi i ́ \alpha\right)$. O fato de que Aristóteles não discuta detidamente o aspecto emocional da conduta gananciosa (e tampouco o faça a respeito da conduta justa) não justifica, por si só, a visão segundo a qual a justiça parcial (assim como a justiça geral) se distinguiria das demais virtudes por não envolver emoção em sua atualização. Tal visão é defendida no clássico comentário de Tomás de Aquino, para quem a justiça - geral ou parcial - se distinguiria das outras virtudes do caráter por ter seu princípio de ação exclusivamente na vontade do agente, sem influência de qualquer emoção (Sententia Libri Ethicorum, Liber Quintus, Lectio 1, 1129a6, 72-76). ${ }^{29}$

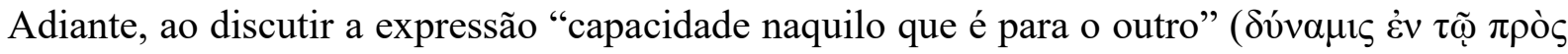
Ě $\varepsilon \rho o v)$, mencionada em P3[9], eu mostro como essa visão de que possa existir uma virtude do caráter não-emocional é incongruente com a concepção de virtude do caráter que consta do livro II da Ética a Nicômaco.

Por ora eu me concentro no prazer do ganancioso. Segundo P3 [10] esse prazer decorre da aquisição do proveito indevido ( $\kappa \varepsilon ́ p \delta \delta \varsigma)$. Sendo esse o caso, e em consonância com as conclusões alcançadas no tópico anterior, o prazer sentido pelo ganancioso está contextualizado na dinâmica interpessoal das ações injustas, onde o proveito que ele angaria corresponde ao prejuízo que ele causa a outros. A questão fundamental é, portanto, a seguinte: o prazer que move o ganancioso diria respeito simplesmente ao bem envolvido nas interações ou, ao contrário, diz respeito também à própria dinâmica interpessoal dessas interações, i.e., diz respeito ao modo como agente se porta face àquelas pessoas que padecem suas ações?

\footnotetext{
${ }^{28}$ Vide nota 8 acima.

${ }^{29}$ Eis o texto da passagem mencionada: "Deve-se considerar também que ele explicou adequadamente a justiça por meio da vontade, na qual não existem emoções e que, no entanto, é princípio de ações exteriores, donde se segue que é o sujeito próprio da justiça, a qual não diz respeito a emoções" (Et est considerandum, quod convenienter notificavit iustitiam per voluntatem, in qua non sunt passiones et tamen est exteriorum actionum principium, unde est proprium subiectum iustitiae quae non est circa passiones.).
} 
$\mathrm{Na}$ primeira interpretação, o agente ganancioso deve ser caracterizado como alguém muito desejoso de bens e que sente, por isso, prazer em obtê-los, mesmo que essa obtenção por ventura se dê através de proveito indevido. É apenas incidentalmente que o ganancioso acaba por prejudicar outra(s) pessoa(s), aquelas que se encontram no outro polo das suas interações. Afinal, a estrutura interpessoal das suas ações implica que ele só pode angariar o proveito indevido, a quota excessiva do bem, na medida em que alguém do outro lado da interação sofre a desvantagem correlata. Porém, ele não sente prazer no advento dessa desvantagem, apenas na aquisição da maior quota possível do bem. Na segunda interpretação, i.e., na hipótese em que o prazer do ganancioso diz respeito à própria estrutura interpessoal da sua ação, ele deve ser caracterizado como alguém mais perverso. Ganancioso seria quem sente prazer em angariar bens em detrimento de outras pessoas.

Duas razões me fazem optar pela segunda interpretação. A primeira delas diz respeito

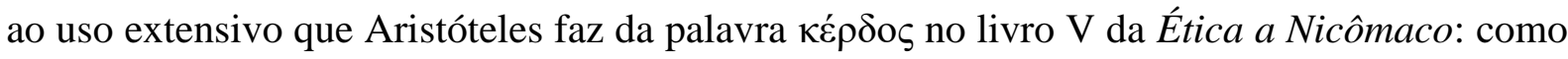
mostrei no tópico precedente, para além da acepção específica de proveito pecuniário indevido, a palavra designa também danos relativos a outros tipos de bem, como a integridade física, a honra e a vida. A distinção entre, de um lado, o proveito indevido que apraz ao ganancioso, e, de outro, um dano incidental e por isso sem relação com o prazer, é mais difícil, senão impossível, de ser estabelecida no caso dos atos injustos envolvendo bens de natureza nãopecuniária. Alguns exemplos de ações injustas que eu mencionei no tópico anterior - homicídio, calúnia, agressão - sugerem que o ganancioso age por vezes motivado precisamente pelo desejo de causar um determinado dano a outrem, dano do qual não lhe provém qualquer vantagem pecuniária. Por exemplo, é frequente que quem comete um homicídio deseje apenas que a sua vítima sofra a desvantagem de ser privada da própria vida; quem calunia outrem pode bem desejar apenas danificar a honra ou a reputação do caluniado; quem comete uma agressão, apenas atacar a integridade física alheia. ${ }^{30}$ Não há, nesses casos, qualquer diferença entre o proveito angariado pelo ganancioso e o dano que esse proveito causa para outrem - ao contrário, o proveito almejado pelo agente injusto parece ser precisamente o dano que ele causa àquele

\footnotetext{
${ }^{30}$ Existem, por óbvio, exemplos desses crimes nos quais o agente visa algum proveito pecuniário como resultado. Esse seria o caso, por exemplo, do matador de aluguel, de quem é pago para caluniar um terceiro ou para agredi-lo fisicamente. Porém, mesmo tais exemplos não afastam a interpretação que defendo: quem paga o matador de aluguel, o agressor, e o caluniador - ou seja, o agente injusto principal - o faz porque lhe apraz tirar a vida, a honra ou a integridade física da vítima desses crimes.
} 
Journal of Ancient Philosophy ISSN 1981-9471 - FFLCH/USP www.revistas.usp.br/filosofiaantiga
J. anc. philos. (Engl. ed.), São Paulo, v.13, n.2. p. 109-145, 2019.

DOI: http://dx.doi.org/10.11606/issn.1981-9471.v13i2p109-145

que padece sua ação. ${ }^{31}$ Logo, o prazer decorrente do proveito indevido é um prazer em prejudicar outras pessoas.

Já as interações de natureza pecuniária admitiriam, ao que parece, a primeira interpretação: é mais fácil conceber que o ganancioso age nesses casos movido por um desejo excessivo pela riqueza e termina por ocasionar, incidentalmente, danos a terceiros, sem que o dano lhe seja prazeroso. No entanto, me parece que mesmo nesses casos a segunda interpretação é mais plausível: o ganancioso sentiria prazer não apenas em conseguir a maior quota possível da riqueza, mas sentiria prazer particularmente em tirá-la de outra pessoa. Minha posição, nesse caso, decorre da segunda razão pela qual eu opto por interpretar o prazer do ganancioso como dizendo respeito à própria dinâmica interpessoal da sua ação. Se nós restringimos o prazer sentido pelo ganancioso apenas ao ato de obter a riqueza almejada, esse prazer se torna quase ou inteiramente indistinguível do prazer característico de outros vícios, em particular da avareza ( $\alpha \dot{v} \varepsilon \lambda \varepsilon v \theta \varepsilon \rho i ́ \alpha)$. A pessoa que tem um caráter avaro se nega a dar ou emprestar dinheiro a quem precisa porque ela sente prazer em reter ou estar na posse desse dinheiro (1107b914;1121b12-1122a13). Se o prazer sentido pelo injusto só se refere à quota excessiva de riqueza angariada na interação injusta, tal prazer é muito parecido com ou talvez idêntico ao prazer experimentado pelo avaro na retenção da própria riqueza. Mas quando nós comparamos as circunstâncias de ação desses dois vícios - avareza e ganância - a natureza interpessoal da ação gananciosa é incontornável: ao avaro apraz demasiadamente reter a sua riqueza, de sorte que ele não consegue compartilhar dela com quem precisa, sem que isso implique qualquer desejo ou prazer em prejudicar esses necessitados, ao passo que ao ganancioso apraz obter riquezas que ele só pode angariar tirando-as de outros. $\mathrm{O}$ desvalor do outro, sendo um elemento

\footnotetext{
${ }^{31}$ Esses exemplos de crimes contra a vida e a integridade física alheia, tão importantes na justiça corretiva, mostram como a leitura restritiva do rol dos bens externos dos quais se ocupa a justiça parcial - por exemplo, a leitura de Young (2006, p.183), mencionado na nota número 21 - está equivocada. Um indício significativo da insuficiência dessa leitura está na dificuldade de Young em compreender o proveito obtido pelo adúltero ganancioso, mencionado por Aristóteles em P2: "The most straightforward way to construe the profit example is to say, for example, that the second man seduces the woman because someone paid him to do it, or because he wished to gain entry into her house in order to steal something. Perhaps we could construe profit broadly, so that getting more physical pleasure than he deserves, or disgracing the woman, or her husband, or her family, counts as profit (though it is unclear how this counts as securing excessive money, honor or safety - the goods with which justice and injustice are concerned)" (Young, 2006, p.191). Os itálicos são meus, e a passagem mostra como a leitura restritiva do autor impede que ele compreenda o sentido amplo que Aristóteles confere à palavra 'kerdos' no livro V da Ética a Nicômaco, tema tratado no tópico anterior.
} 
necessário da estrutura da ação injusta, esse desvalor também se incorporaria ao prazer sentido pelo ganancioso ao agir ${ }^{32}$.

Quanto ao prazer experimentado pelo homem justo nas suas interações, não há qualquer caracterização no livro V da Ética a Nicômaco. No entanto, Aristóteles faz, logo no início do mesmo livro, uma observação a respeito das disposições de caráter - $\check{\varepsilon} \xi \varepsilon 1 \varsigma$ - que é útil para o discernimento do que possa ser aprazível ao homem justo em suas ações. "Frequentemente uma disposição é discernida a partir da disposição oposta" (1129a17-18), e o exemplo mencionado é o discernimento do que é a má forma física a partir do conhecimento do que seja a boa forma física: sendo essa última a firmeza da carne, a primeira é a flacidez da carne (1129a19-23). Nesse sentido, é possível buscar algum discernimento, mesmo que rudimentar, a respeito do prazer sentido pelo homem justo nas suas interações a partir do prazer sentido pelo homem ganancioso nas mesmas interações: se ao ganancioso apraz angariar proveito indevido, e portanto, violar a igualdade e prejudicar quem está no outro polo da interação, ao homem justo apraz respeitar essa igualdade e, portanto, angariar na interação apenas aquilo que lhe cabe.

\section{Existe emoção nas ações justas e injustas?}

\section{IV.1. O problema e as diferentes interpretações}

Se a temática do prazer envolvido nas ações justas e gananciosas requer, em razão das evidências textuais modestas, cautela da parte do intérprete - e por isso não desenvolvo o ponto para além das considerações acima - a temática da emoção coloca dificuldade ainda maior. Conforme a introdução desse estudo já anotava, não há no livro V da Ética a Nicômaco uma discussão explícita da emoção; no início desse tópico, por sua vez, eu sugeri que há apenas uma alusão ao aspecto emocional das ações justas e injustas na expressão "capacidade naquilo que

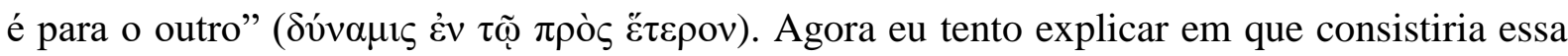
alusão. O ponto de partida é a constatação de que essa expressão é ao mesmo tempo importante - na medida em que nela reside o atributo comum que distingue justiça geral e justiça parcial

32 Kraut (2002, p.138) adota interpretação do prazer ganancioso semelhante à minha em sua caracterização do ato de adultério mencionado por Aristóteles em P2: "the man who commits adultery in order to make a profit does not merely love Money, for if that were the only emotional disorder his act displayed, it would merely exhibit the vice of excessive love of wealth. Rather, as Aristotle says, he takes pleasure in his gain (1130b4). What he means is that the unjust person is glad that his gain comes at the expense of another, because causing that suffering is part of his motive". 
das demais virtudes estudadas no tratado - e inegavelmente obscura. Afinal, o que Aristóteles pretende dizer ao afirmar em P3 [9] que as duas formas da justiça têm uma "capacidade/potência naquilo que está voltado ao outro"?

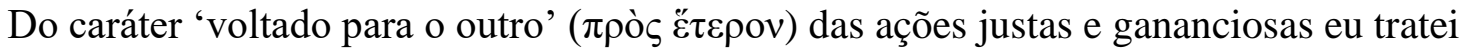
no tópico anterior. Me refiro à natureza interpessoal dessas ações, que engendram, respectivamente, relações equilibradas nas quais os dois polos angariam aquilo que lhes cabe, e relações desequilibradas nas quais o proveito indevido obtido por um dos polos corresponde

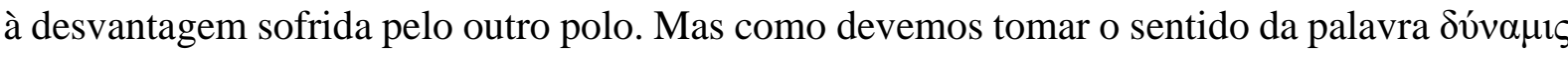

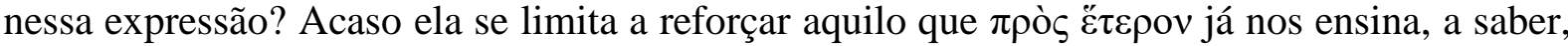
que a justiça parcial e a ganância são disposições atualizadas em ações de estrutura relacional?

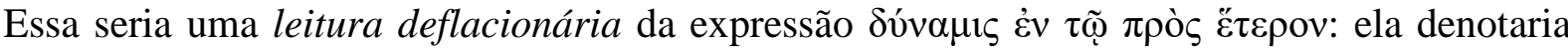
simplesmente o fato de que as ações justas e gananciosas decorrem de uma capacidade dos seres humanos em interagir face a determinados bens; essa leitura é deflacionária porque, embora não negue explicitamente o aspecto emocional da efetuação das ações justas e gananciosas, como faz a leitura Tomista, ela tampouco busca explica-lo detidamente.

A maior parte dos intérpretes parece adotar, mesmo que tacitamente, essa leitura deflacionária. O caso dos tradutores-comentaristas é especialmente notável nesse sentido.

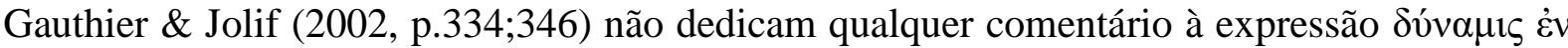

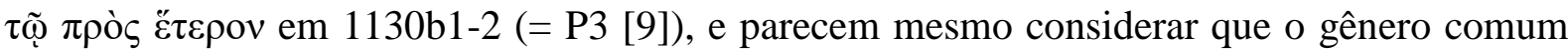
que, segundo P3, unificaria justiça geral e justiça parcial, não é sequer um gênero de disposições de caráter, mas de ações relacionais. ${ }^{33}$ Zingano $(2017$, p.95), por sua vez, traduz ö $\mu \varphi \omega[\ldots]$ غ่v

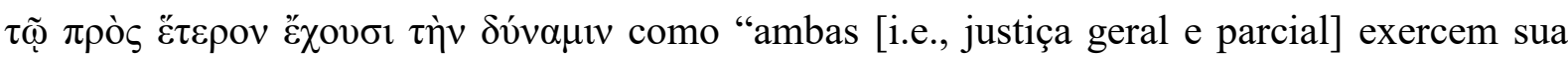
capacidade na relação com outrem", sem tratar nos comentários do sentido de 'capacidade' nesse contexto (p.170-171). Tampouco Jackson (1879, p.13) comenta a respeito da palavra

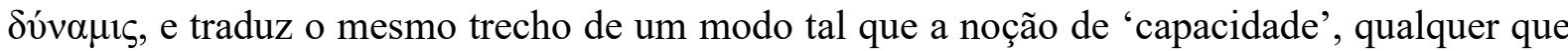
seja o seu sentido, desaparece: "both being occupied with a man's relations to his neighbour".

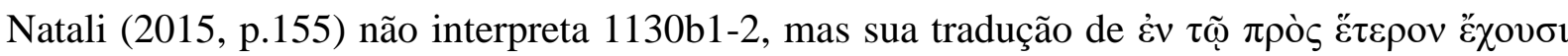
$\tau \eta ̀ v ~ \delta v ́ v \alpha \mu ı v$ sugere a adesão à leitura deflacionária: "draw their efficacy in relation to the other".

Uma outra possibilidade de interpretação, aquela que defendo e que chamo de leitura plena, parte do fato de que o texto grego de P3 também se refere ao prazer experimentado pelo

\footnotetext{
33 “[...] Aristote reconnaitra plus loin que les deux justices rentrent dans un genre commun: les rapports avec autrui» (Gauthier \& Jolif, 2002, p.334).
} 
ganancioso. Contextualizando P3 na teoria aristotélica das virtudes do caráter, onde virtude e vício são potências emocionais, a leitura plena sugere que a menção do prazer é um indício

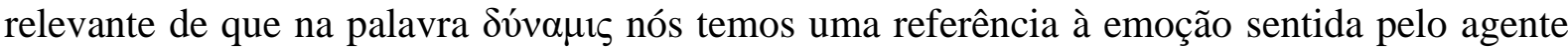

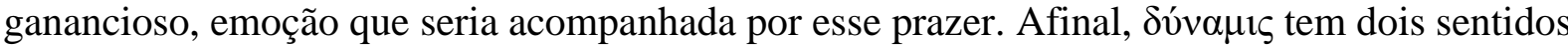
técnicos na teoria aristotélica das virtudes exposta no livro II da Ética a Nicômaco: por um lado, a capacidade inata de sentir emoções que são acompanhadas por prazer ou desgosto (1105b2125); por outro, o fato de que toda virtude do caráter, uma vez desenvolvida pela conduta reiterada e pela disciplina das emoções, é uma capacidade adquirida para agir (1104a33-b3).

Nos próximos parágrafos defenderei a leitura plena de P3, uma leitura na qual a

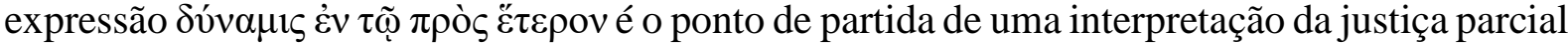
e da ganância como disposições de caráter perfeitamente alinhadas à teoria geral das virtudes e vícios de Aristóteles. Defenderei a superioridade da leitura plena de P3 face à leitura deflacionária (IV.2) e também face a duas interpretações contemporâneas não-deflacionárias da justiça parcial e da ganância (IV.3). Essas duas interpretações falham porque, embora não deixem de lado o aspecto emocional dessas disposições, são incapazes de concebê-lo do modo unificado e consistente que o sistema aristotélico requer. Uma dessas interpretações, defendida por Kraut (1989), não aglutina a justiça e a ganância como virtude e vício relativos a uma mesma emoção, o que é incompatível com o modo como Aristóteles concebe as virtudes e os vícios do caráter. A outra interpretação, defendida por Williams (1980), sugere que não existe uma unidade motivacional e emocional das práticas de injustiça parcial, e que a noção de ganância

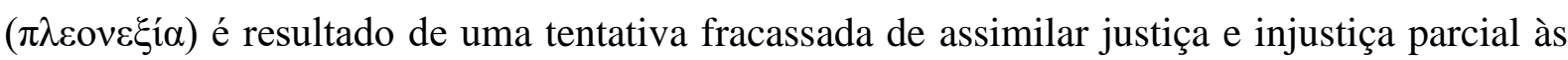
demais disposições do sistema aristotélico. A interpretação que defendo nesse estudo, portanto, é a mais apta a preservar tanto a consistência da teoria geral das virtudes e dos vícios defendida por Aristóteles, em especial no livro II da Ética a Nicômaco, quanto a variedade das práticas de justiça descritas no livro V do mesmo tratado.

\section{IV.2. A superioridade da leitura plena sobre a deflacionária}

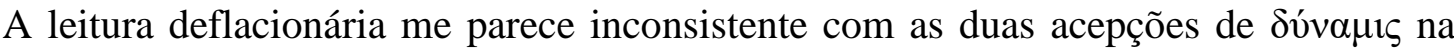
teoria aristotélica das virtudes do caráter. A razão disso é que ambas as acepções da palavra apontam para a relação intrínseca entre disposição do caráter e emoção. No capítulo 5 do livro

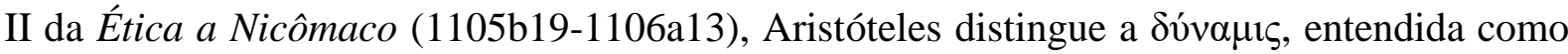


Journal of Ancient Philosophy ISSN 1981-9471 - FFLCH/USP www.revistas.usp.br/filosofiaantiga
J. anc. philos. (Engl. ed.), São Paulo, v.13, n.2. p. 109-145, 2019.

DOI: http://dx.doi.org/10.11606/issn.1981-9471.v13i2p109-145

capacidade emotiva, da $\check{\varepsilon} \xi ı \zeta$, i.e., da disposição do caráter. Seu objetivo é afirmar que as

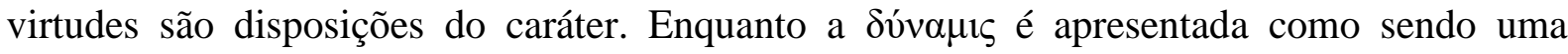
capacidade inata de sentir emoções, inerente na alma humana por natureza, a $\check{\not} \xi ı \varsigma$ é descrita como sendo aquilo que, na nossa alma, nos dispõe de tal modo que "portamo-nos bem ou mal

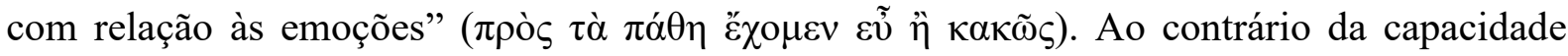
emotiva, a disposição não se origina por natureza - "não nos tornamos bons ou maus por

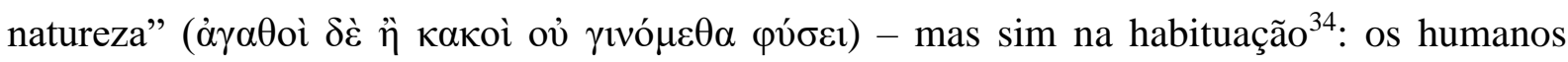
tornam-se bons na medida em que desenvolvem em seu caráter disposições virtuosas, que lhes dispõem a portarem-se bem com relação às emoções, e tornam-se maus na medida em que desenvolvem disposições viciosas, que lhes dispõem a portarem-se mal com relação às emoções. Em outras palavras, tanto a capacidade emotiva quanto a disposição dizem respeito

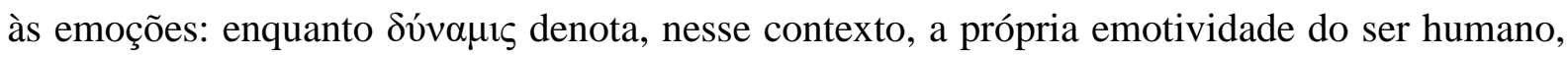
inata e maleável (i.e., passível de educação que a transforme), a ह̌ $\xi 1 \zeta$ denota a situação resultante da educação disciplinadora das emoções, a saber, a capacidade de agir bem e sob influência adequada das emoções. A primeira seria uma capacidade emocional inata, ao passo que a segunda seria uma capacidade adquirida a partir da disciplina das emoções.

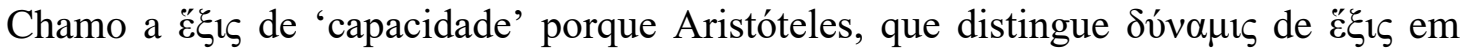

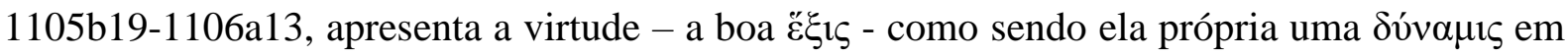
1103a26-1103b2. Eis o texto:

\section{P5}

"[1] Além disso, daquelas coisas que nos advêm por natureza, nós recebemos primeiro as capacidades, e depois exercemos as atividades (o que é evidente a respeito das percepções: pois não é a partir do frequentemente enxergar ou frequentemente escutar que adquirimos as percepções, mas, ao contrário, tendo-as, nós as exercemos, e não, exercendo-as, nós então as temos). [2] Já as virtudes, nós as adquirimos tendo-as exercido antes, igual ao que acontece com respeito às diversas artes: pois é preciso tê-las aprendido para então pratica-las, e praticando-as é que as aprendemos, por exemplo, construindo casas nos tornamos construtores e tocando cítara nos tornamos tocadores de cítara. [3] Desse modo também se dá que realizando ações justas nos tornamos justos, ações temperantes, temperantes, e ações corajosas, corajosos".

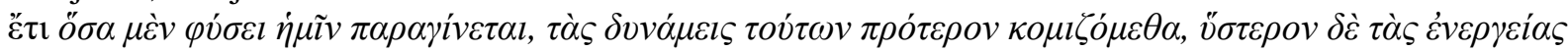

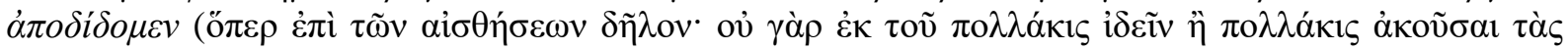

\footnotetext{
${ }^{34}$ Aristóteles não afirma expressamente em Ethica Nicomachea 1105b19-1106a13 (EN II.5) que as disposições se originam a partir da conduta habitual. Ele diz apenas que "falamos a respeito disso

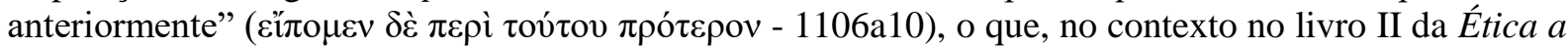
Nicômaco, é uma referência ao processo de educação moral dos agentes por meio da conduta reiterada (II.1), da disciplina das emoções (II.2), e da transformação dos prazeres (II.3). Tal processo de educação culmina no advento da virtude, a disposição que habilita o ser humano a agir moralmente "de modo

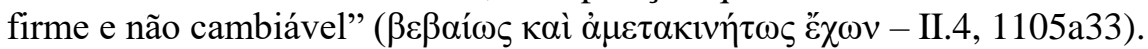


Journal of Ancient Philosophy ISSN 1981-9471 - FFLCH/USP www.revistas.usp.br/filosofiaantiga
J. anc. philos. (Engl. ed.), São Paulo, v.13, n.2. p. 109-145, 2019.

DOI: http://dx.doi.org/10.11606/issn.1981-9471.v13i2p109-145

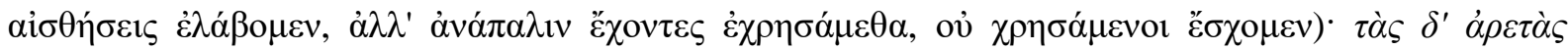

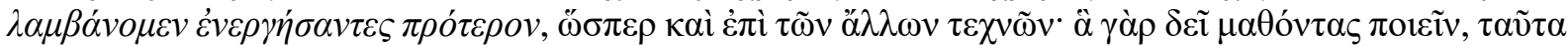

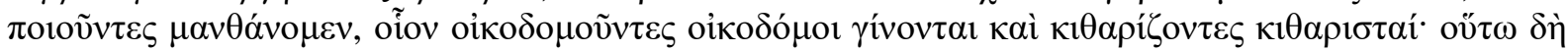

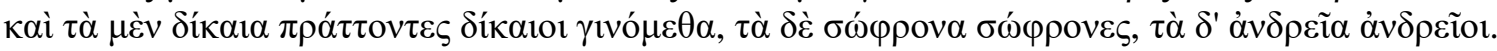

Em itálico eu marquei a contraposição entre as capacidades inatas, mencionadas em P5 [1] e as capacidades adquiridas, por exemplo as virtudes e as artes, mencionadas em P5 [2]. ${ }^{35}$ Aristóteles se serve, para fazer essa contraposição, da típica estrutura envolvendo as partículas

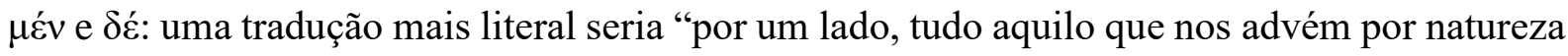

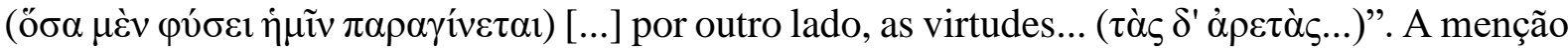
dos exemplos da visão e da audição entre parênteses em P5 [1] confirma que se trata efetivamente ali de capacidades ou potências inatas: nós enxergamos porque nascemos com a capacidade de enxergar e escutamos porque nascemos com a capacidade de escutar. Desse tipo são também aquelas capacidades emotivas que Aristóteles distingue das disposições de caráter em 1105b19-1106a13: nós sentimos raiva, medo e apetite, porque nascemos com a capacidade para sentir tais emoções. Já as virtudes, mencionadas em P5 [2] e exemplificadas em P5 [3], nós não as recebemos por natureza para, então, exercê-las; ao contrário, exercendo reiteradamente certos tipos de atos, nós nos tornamos virtuosos. Tal como as artes, as virtudes são capacidades que precisam ser adquiridas.

Embora estrutura do texto grego de P5 sugira ela própria que as virtudes e as artes são

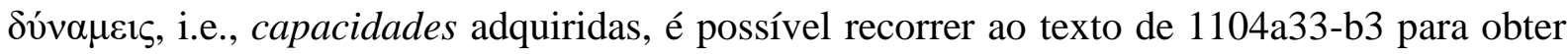
uma evidência mais eloquente nesse sentido:

\section{P6}

"a partir do evitar os prazeres nós nos tornamos temperantes, e tendo nos tornado tais, somos maximamente capazes de evita-los; de modo semelhantes se passa também com a coragem habituando-nos a desprezar as circunstâncias temíveis e suportando-as nós nos tornamos corajosos, e tendo nos tornado tais nós seremos maximamente capazes de suporta-las".

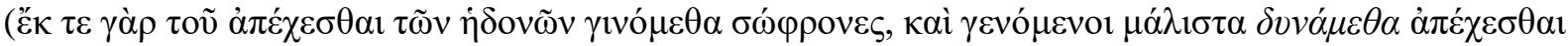

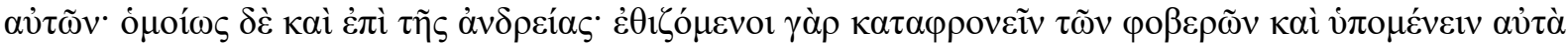

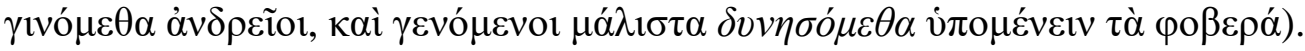

\footnotetext{
${ }^{35}$ Vide, nesse sentido, Gauthier \& Jolif (2002, p.109): "ce que nous possédons par nature est en nous d'abord à l'état de capacité, de puissance, et nous en exerçons ensuite les actes ; s'il s'agit des vertus, au contraire, nous commençons par exercer les activités et c'est l'exercice qui nous confère la puissance ». Os comentaristas vêem nessa distinção da Ética a Nicômaco um eco da distinção dos três tipos de capacidade em Metaphysica 1047b31-35: capacidade inata, capacidade resultado da habituação, e capacidade resultado do estudo.
} 
Journal of Ancient Philosophy ISSN 1981-9471 - FFLCH/USP www.revistas.usp.br/filosofiaantiga
J. anc. philos. (Engl. ed.), São Paulo, v.13, n.2. p. 109-145, 2019.

DOI: http://dx.doi.org/10.11606/issn.1981-9471.v13i2p109-145

A aquisição da virtude da temperança tem por consequência que nós somos capazes $\delta v v \alpha ́ \mu \varepsilon \theta \alpha$-de praticar, em máximo grau, aquelas ações cuja reiteração engendrou nossa virtude, i.e., evitar os deleites físicos inconvenientes; a aquisição da coragem, por sua vez, implica que

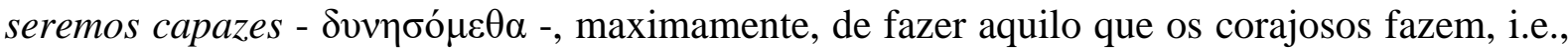
suportar as circunstâncias temíveis. Além de demonstrar que Aristóteles concebe as virtudes (e, portanto, as disposições do caráter) como capacidades, o que se observa pelo uso do verbo $\delta v ́ v \alpha \mu \alpha 1$, essa passagem aponta também para a relação que essas capacidades adquiridas que são as virtudes têm com as nossas emoções. ${ }^{36} \mathrm{O}$ homem corajoso é capaz de suportar as circunstâncias temíveis porque, diferente do covarde, ele não é acometido em demasia pela emoção do temor, que dificulta enormemente ao covarde suportar tudo quanto seja temível (e torna tal tarefa assaz desgostosa); por outro lado, diferente do temerário, o corajoso tampouco é acometido em demasia pela emoção do arrojo, que torna a circunstância temível demasiadamente atraente para o temerário, e não simplesmente algo que ele precisa suportar, donde o seu desgosto em recuar diante dos perigos que não devem ser enfrentados.

Em suma, as emoções disciplinadas do virtuoso facilitam a prática da ação virtuosa e tornam-lhe essa prática prazerosa, ao passo que as emoções desordenadas - excessivas ou deficientes - do vicioso dificultam a prática da ação virtuosa e tornam-lhe essa prática desgostosa. Ambos nasceram com a mesma capacidade primeira que os faz suscetíveis às emoções, mas cada um deles adquiriu, em razão da disciplina ou indisciplina de suas emoções, uma capacidade segunda diferente, a disposição ou है $\xi 1 \zeta$.

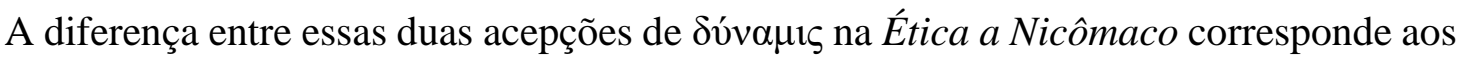

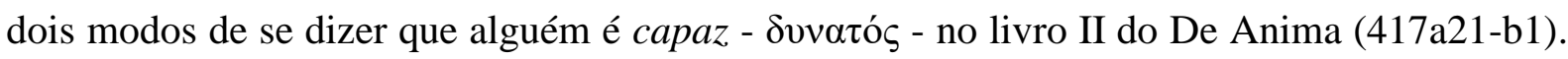
Aristóteles explica-os a partir do exemplo do 'conhecedor em potência', isto é, aquele que possui a capacidade de conhecer. É capaz de conhecer, por um lado, todo aquele que pertence a um determinado gênero ou é dotado de uma determinada matéria: nesse sentido, todo ser que pertence ao gênero humano é conhecedor, pois sua forma e sua matéria o capacitam a aprender

\footnotetext{
${ }^{36}$ Tomemos, como exemplo, essa observação feita ainda no livro II do tratado: "Por exemplo, tanto no sentir temor quanto no arrojar-se, no sentir apetite, no enraivecer-se e no compadecer-se, e em geral no sentir prazer e desgosto, há o excesso e a deficiência, e nenhum dos dois está bem: mas experimentar tudo isso quando se deve, diante do que se deve, para com quem se deve, com vistas ao que se deve e como se deve, isso é um meio-termo e o que é melhor, precisamente o que é característico da virtude"

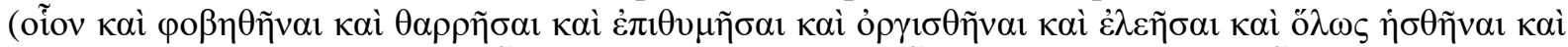

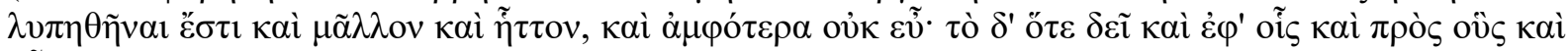

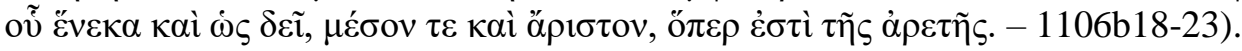


coisas. Trata-se aqui de uma capacidade primeira e inata, que todo humano tem, tal como a capacidade de sentir emoções. Por outro lado, é capaz de conhecer todo aquele que, na ausência de impedimento externo, pode exercer o conhecimento ao seu bel prazer: nesse sentido, apenas aquele ser humano que já aprendeu alguma coisa é capaz de conhece-la, isto é, exercer ao seu bel prazer o conhecimento adquirido. Trata-se aqui de uma capacidade segunda ou adquirida, não-inata, tal como o são as disposições de caráter. A diferença entre ambas é que a capacidade adquirida de conhecer foi adquirida na medida em que o homem "foi alterado através do

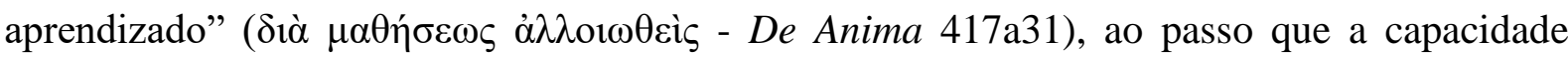
adquirida de agir, a virtude, foi adquirida por meio da habituação (E.N. 1103a14-23).

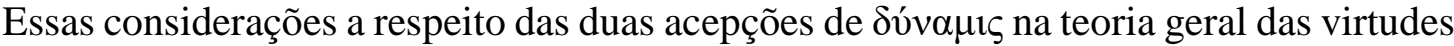
do caráter de Aristóteles sugerem a insuficiência da interpretação deflacionária adotada pela generalidade dos intérpretes: não há, na teoria das virtudes de Aristóteles, virtudes do caráter

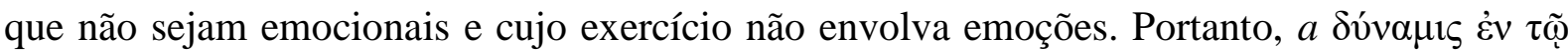

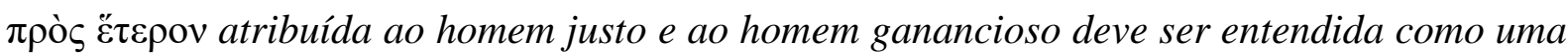
capacidade adquirida, resultante da educação (ou ausência de educação) de uma determinada emoção. Tal como a covardia é uma capacidade adquirida pelo agente que não educou as emoções do medo e do arrojo, de sorte que ele se dispõe a fugir de todos os perigos com os quais se depara e sente grande desgosto em enfrentar tais perigos, também a ganância ou injustiça parcial seria uma capacidade adquirida pelo agente que não educou uma determinada emoção envolvida no agir face ao outro - por isso essa capacidade é qualificada em P3 [9] como

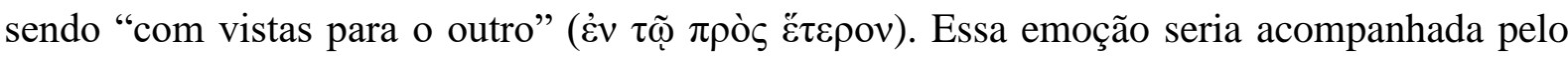
prazer mencionado em $\mathrm{P} 3[10]$.

Mantida a cautela com que me propus a tratar do tema do prazer envolvido nos atos de justiça parcial e de ganância, faço a seguinte sugestão. Aristóteles estaria dizendo em P3 [9-11] que a Justiça Parcial e Ganância, Justiça e Injustiça Geral, são todas disposições, isto é, capacidades adquiridas opostas, duas virtudes e dois vícios. Todos se desenvolvem a partir da educação ou ausência de educação de uma determinada capacidade emotiva. Embora a emoção propriamente dita não seja nomeada na passagem, é possível afirmar, com base nas considerações feitas ao longo desse tópico, que se trata de uma capacidade inata que nos torna emotivos de algum modo nas nossas interações uns com os outros. Em outros termos, nós falamos de uma espécie de "emoção altruística". Quando essa capacidade emotiva inata é bemeducada, ela dá origem às capacidades adquiridas que são as virtudes da Justiça Geral e da 
Justiça Parcial. A pessoa dotada da virtude da Justiça Parcial seria alguém que, tendo sido bemeducado, é emotivamente propenso, em suas interações, a considerar o bem alheio. Por isso essa pessoa não tenta obter proveitos indevidos nas transações em que participa. Quando, ao contrário, a capacidade emotiva altruística inata não é bem-educada, as duas modalidades de Injustiça tendem a se consolidar na alma da pessoa. Nesse sentido, o prazer que a pessoa gananciosa, i.e., injusta parcialmente, sente ao tirar proveito às expensas do outro acompanharia uma emoção altruística que não foi bem desenvolvida pela educação moral. Essa afirmação se enquadra com a minha sugestão anterior de que o prazer sentido pelo homem ganancioso envolve o desvalor daquelas pessoas em detrimento das quais ele extrai seus proveitos indevidos. O ganancioso seria alguém que, envolvendo-se em interações, é emotivamente propenso a desprezar o bem alheio. Ao excesso de bens que ele busca na ação, que é o proveito

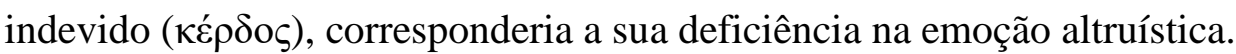

\section{IV.3. A superioridade da leitura plena em relação a outras leituras contemporâneas}

A maior dificuldade da interpretação do aspecto emocional das ações justas e injustas que defendo nesse estudo é o fato de que Aristóteles não nomeia explicitamente a emoção altruística que seria sentida pelos agentes justos e injustos, limitando-se a afirmar que justiça e injustiça são, enquanto virtude e vício, "capacidades com vista para o outro" (vide P3[9]). Cabe ressaltar, porém, que emoções e disposições inominadas são comuns na sua obra: em 1107b2 se diz explicitamente que inúmeras disposições não possuem nome, por exemplo, a disposição caracterizada pelo excesso de destemor (1107b1) ou pela deficiência na busca dos prazeres físicos - o termo 'insensível' ( $\alpha$ $v \alpha i ́ \sigma \theta \eta \tau o \varsigma)$ é cunhado, ao menos enquanto conceito filosófico,

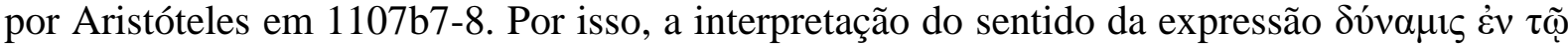

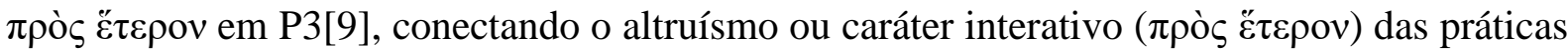
de justiça descritas no livro V da Ética a Nicômaco com as observações a respeito das capacidades ( $\delta v_{v} \alpha \mu \varepsilon 1 \varsigma$ ) inatas e adquiridas feitas ao longo do livro II do mesmo tratado, permite uma reconstrução da emotividade envolvida nos atos justos e injustos que é consistente com a teoria aristotélica das virtudes e vícios do caráter. Nesse sentido, a interpretação avançada nesse estudo é mais interessante do que outras duas tentativas contemporâneas de articular o aspecto emocional das práticas justas e injustas. Ao contrário daquela leitura que chamei de deflacionária, essas duas interpretações não negligenciam a influência da emoção sobre as ações 
justas e injustas; mas, ao contrário da interpretação que apresentei no tópico anterior, elas não são capazes de conceber essa influência de modo tão consistente com a teoria aristotélica das virtudes do caráter.

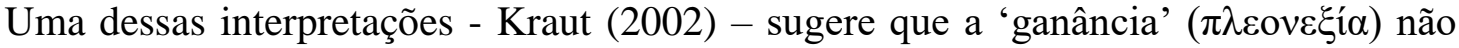
seria um outro nome para o vício da injustiça parcial, mas o nome da sua emoção característica. A pessoa dotada da disposição de caráter chamada de injustiça parcial seria, nesse caso, alguém que sente uma emoção chamada de ganância, e que por isso deseja tirar vantagem dos outros. Já a pessoa justa, isto é, dotada da disposição de caráter chamada de justiça parcial, seria alguém que não sente essa emoção. Essa interpretação possui uma inconsistência grave com a teoria aristotélica das virtudes e vícios do caráter, a saber, ela atribui ao vício do caráter (=injustiça) uma emoção exclusiva (=ganância), isto é, uma emoção que não pode ser atribuída à virtude correlata (=justiça). Não é possível, pois, afirmar que o injusto é alguém que sente um excesso de ganância, ao passo que o justo seria alguém que sente ganância na medida adequada ${ }^{37}$. No sistema aristotélico, as virtudes e vícios que se opõem dizem respeito à mesma emoção: coragem, covardia e temeridade, por exemplo, dizem respeito às emoções do medo e da ousadia (1107a33-b4); temperança, intemperança e insensibilidade dizem respeito ao apetite pelo prazer (1107b4-8), e assim por diante. Essa unidade de virtude e vícios em torno de uma mesma emoção comum é a fundação da teoria da mediedade: a deficiência, o excesso e o ponto médio contrapõem-se um ao outro justamente porque dizem respeito a uma mesma emoção (1106a26b27). Se o homem injusto sente a emoção da ganância e o homem justo não a sente, Aristóteles teria concebido uma virtude não-emotiva (tal como na leitura de Tomás de Aquino) que se opõe a um vício emotivo, uma concepção que não se enquadra com sua teoria das virtudes e vícios do caráter.

Uma outra interpretação contemporânea do aspecto emocional das práticas justas e injustas - Williams $(1980)^{38}$ - também me parece menos interessante do que aquela que é

\footnotetext{
${ }^{37}$ A dificuldade dessa linha interpretativa é reconhecida por seu próprio defensor: "In each case, there is some emotion that needs to be mastered, and vices arise because there are two opposed ways of failing to master that emotion. But this is precisely what is lacking in Aristotle's analysis of justice and injustice. The emotional state that makes someone an unjust person in the narrow sense is pleonexia. But being a just person is not a matter of having that same emotion to the right extent; rather, it is a matter of not having such an emotion at all. The just person has no desire to gain at the expense of others, and to enjoy their losses. His virtue does not consist in handling well the emotion that the unjust person handles poorly" (Kraut, 2002, p.160).

${ }^{38}$ Ver Williams, Bernard. "Justice as Virtue" in Rorty, A..O. (org.). Essays on Aristotle's Ethics. (University of California Press, 1980, p.189-200).
} 
apresentada nesse estudo. Ela sugere o esvaziamento semântico do termo 'ganância': ao invés

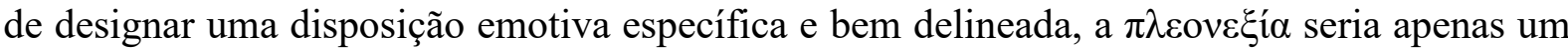
rótulo atribuído a um conjunto de motivos variados e sem interconexão, que teriam em comum apenas o fato de que eles tornam um agente indiferente às questões de justiça. Por exemplo, alguém poderia tomar uma decisão injusta porque tem preguiça de examinar as circunstâncias do caso; outra pessoa poderia fazê-lo porque acha divertido o resultado injusto; uma terceira pessoa poderia praticar uma ação injusta em busca de vantagens sexuais, e assim por diante ${ }^{39}$. Em outros termos, Williams defende que a injustiça parcial não possuiria aquela unidade e consistência motivacional que caracteriza as demais disposições viciosas e virtuosas do caráter: Aristóteles teria, a seu ver, sacrificado um exame centrado nas peculiaridades da justiça e da injustiça em favor de um alinhamento dessa virtude e desse vício com sua teoria geral das virtudes e vícios do caráter. ${ }^{40}$ Segundo essa interpretação da motivação do agente injusto ou ganancioso, o vício da injustiça (e, portanto, também a virtude da justiça) não possuiriam a coesão emocional que caracteriza as disposições de caráter do sistema aristotélico: ações injustas poderiam ocorrer sob a influência de uma miríade de emoções diferentes. Nesse contexto, porém, torna-se difícil compreender como a injustiça parcial pode ser considerada uma disposição de caráter uma e específica.

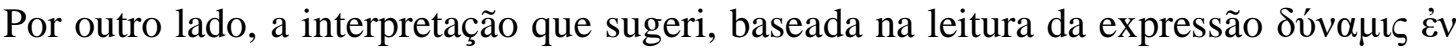

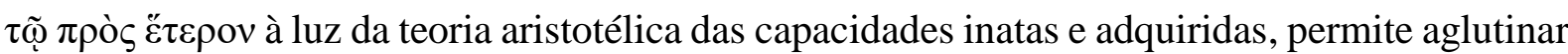
a variedade de motivos que movem o homem ganancioso em uma unidade emocional consistente. Todos esses motivos poderiam ser traçados ao desprezo pelo bem alheio, isto é, a uma emoção altruística deficiente que resulta da má educação do agente ganancioso. Por não se preocupar com o bem alheio, o agente ganancioso comete crimes contra seus concidadãos, angaria mais do que lhe caberia nas distribuições, não respeita as trocas comerciais, considera divertido tomar decisões injustas, pensa que a própria gratificação sexual é mais relevante do

\footnotetext{
${ }^{39}$ Essa posição e esses exemplos encontram-se no texto de Williams (1980, p.191-193).

${ }^{40}$ Nesse sentido, Williams entende que o exame adequado da justiça e da injustiça parciais requer certo distanciamento com relação à teoria geral das virtudes exposta no livro II da Ética a Nicômaco: “[...] the unjust person is not necessarily greedy or anxious to get more for himself, and insofar as Aristotle connects injustice essentially with pleonexia, he is mistaken. The mistake can, moreover, be fairly easily diagnosed in at the systematic level: the vice of adikia has been overassimilated to the other vices of character, so that Aristotle seeks a characteristic motive to go with it, whereas it must be basic to this vice, unlike others, that it does not import a special motive, but rather the lack of one" (Williams, 1980, p.198 - itálicos meus).
} 
que a justiça de uma decisão a ser tomada, etc. Em todo caso, tratar-se-ia de diferentes manifestações de uma mesma deficiência da emoção altruística por parte do agente.

\section{Conclusão}

O exame da virtude da justiça parcial e de seu vício correspondente, a ganância, realizado à luz da teoria aristotélica das disposições de caráter, permite ao intérprete delinear um esboço dessas duas disposições, em que pese a escassez das evidências textuais a respeito do tema. Unindo, de um lado, a cautela necessária para não atribuir a Aristóteles posições que não são suas e, de outro, o dever que se impõe ao intérprete de não negligenciar os indícios textuais que são fornecidos pelo próprio filósofo - indícios escassos, porém inquestionáveis -, meu estudo colhe os seguintes resultados.

Em primeiro lugar, a ação característica da justiça parcial está inserida em contexto relacional ou de interação. Os diversos tipos de relação de igualdade (distribuição, correção, trocas) acarretam interações entre pessoas que buscam repartir ou transacionar bens externos, sobretudo riquezas, embora outros tipos de bens também sejam pertinentes às relações de justiça. A igualdade é, nesse sentido, um equilíbrio presente da interação, seja ela distributiva ou comercial, ao passo que a desigualdade é um desequilíbrio relacional, por exemplo, a situação em que alguém cometeu um crime e outrem padeceu esse mesmo crime. Envolver-se em relações de justiça é agir sobre outrem e padecer aquilo que outrem realiza. Por isso o 'tirar

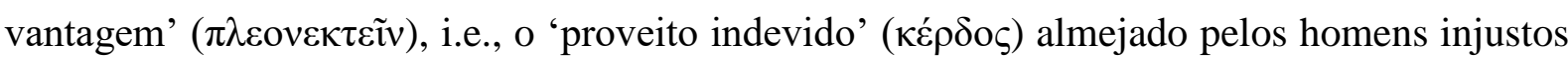
segundo P1-P2-P3 inclui, em razão da estrutura mesma das práticas de justiça, o dano causado a outrem. A descrição do ponto médio que caracteriza a justiça parcial e do excesso e da deficiência que caracterizam a ganância é especialmente esclarecedora da natureza interpessoal das condutas justa e injusta.

Tais considerações a respeito da natureza interpessoal da prática gananciosa sugerem que elas são o contexto no qual se insere o prazer experimentado pelo agente ganancioso. Daí minha sugestão no sentido de que o prazer mencionado em P3 [10] (1130b4), resultante do proveito indevido extraído pelo ganancioso, não diz respeito somente ao bem do qual ele angaria uma quota excessiva que corresponde a tal proveito, mas diz respeito também àqueles que padecem sua ação iníqua. As interações que envolvem bens de natureza não-pecuniária crimes como o homicídio ou a calúnia - são particularmente sugestivas do fato de que prazer 
que o agente ganancioso extrai não advém somente da obtenção da quota excessiva do bem que está em jogo, mas também do lesar a outrem; no caso dos bens pecuniários, por sua vez, a mesma qualificação do prazer é importante, pois de outro modo o ato ganancioso se torna quase, senão inteiramente, indistinguível do ato avaro. Já o prazer experimentado pelo agente justo, embora inarticulado no texto, pode ser compreendido a partir de algumas observações feitas no início do livro V sobre o conhecimento das disposições de caráter: trata-se do prazer que o agente justo tem em respeitar a igualdade das interações, isto é, em angariar apenas aquilo que lhe cabe, respeitando aquilo que pertence ao outro.

Por fim, o último tópico estudado, a emoção envolvida na prática da justiça parcial e da ganância, mostra-se como o de mais difícil articulação. Seu ponto de partida é uma simples

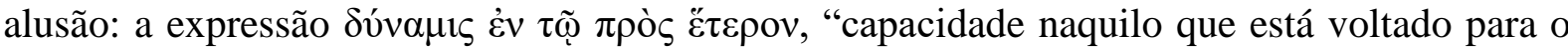

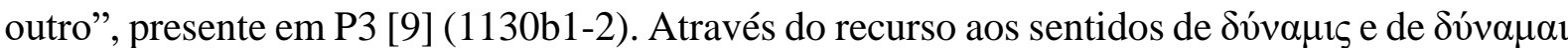
na Ética a Nicômaco, questionei a interpretação deflacionária que a maior parte dos intérpretes adotam para ler tal expressão. Mais do que a efetividade dos atos justos e gananciosos em contextos de interação humana, essa expressão designa também nossa capacidade emotiva ao agir nesses contextos, de sorte que ao agente justo pode ser atribuída uma emoção altruística bem-educada que o faz preocupar-se com o bem das pessoas com quem interage justamente, ao passo que ao agente ganancioso pode ser atribuída a ausência dessa educação, portanto uma deficiência quanto à emoção altruística, que o faz desprezar o bem alheio e sentir prazer em tirar proveito às expensas dos outros.

André Luiz Cruz Sousa Universidade Estadual de Maringá

\section{Referências Bibliográficas}

\section{Obras de Aristóteles}

Bywater, I. Aristotelis Ethica Nicomachea. (Oxford Classical Texts, 1894).

Jaeger, W. Aristotelis Metaphysica. (Oxford Classical Texts, 1957).

Kenyon, F.G. Aristotelis Atheniensium Respublica. (Oxford Classical Texts, 1920). 
Journal of Ancient Philosophy ISSN 1981-9471 - FFLCH/USP www.revistas.usp.br/filosofiaantiga
J. anc. philos. (Engl. ed.), São Paulo, v.13, n.2. p. 109-145, 2019.

DOI: http://dx.doi.org/10.11606/issn.1981-9471.v13i2p109-145

Ross, W.D. Aristotelis De Anima. (Oxford Classical Texts, 1956).

Walzer, R.R., Mingay, J.R. Aristotelis Ethica Eudemia. (Oxford Classical Texts, 1991).

\section{Demais Obras}

Beekes, R.S.P. Etymological Dictionary of Greek. Two Volumes. (Leiden: Brill, 2010).

Chantraine, P. Dictionnaire Étymologique de la Langue Grecque. Histoire des Mots. Avec un Supplément sous la direction de Alain Blanc, Charles de Lamberterie, Jean-Louis Perpillou. (Paris : Klincksieck, 1999).

Gauthier, R.A.; Jolif, Y.J. (ed.). Aristote. L'Éthique à Nicomaque. Tome II - Premiére Partie. Commentaire. Livres I-V. (Louvain-La-Neuve, Éditions Peeters, 2002).

Grant, A. The Ethics of Aristotle. Illustrated with Essays and Notes. Volume II. Fourth Edition, Revised. (London: Longmans, Green and Co, 1885).

Jackson, H. The Fifth Book of the Nicomachean Ethics of Aristotle. (Cambridge University Press, 1879).

Kraut, R. Aristotle. Political Philosophy. (Oxford University Press, 2002).

MacIntyre, Alasdair. After Virtue. A Study in Moral Theory. (University of Notre Dame Press, 1984).

Natali, Carlo. "The search for definitions of justice in Nicomachean Ethics V" in Henry, D./Nielsen, K.M. (ed.) Bridging the Gap between Aristotle's Science and Ethics. (Cambridge University Press, 2015, p.148-168). https://doi.org/10.1017/CBO9780511846397.009

Schofield, Malcom. "Aristotle's Political Ethics" in KRAUT, R. (org.). The Blackwell Guide to Aristotle's Nicomachean Ethics. (Blackwell Publishing, 2006, p. 305-322).

https://doi.org/10.1002/9780470776513.ch14

Stewart, J.A. Notes on the Nicomachean Ethics of Aristotle. (Oxford at the Clarendon Press, 1892).

Tomás de Aquino. Sancti Thomae De Aquino. Opera Omnia Iussu Leonis XIII P. M. Edita. Tomus XLVII. Sententia Libri Ethicorum. Volumen II. Liber Quintus. (Romae: Sanctae Sabinae, 1969).

Williams, Bernard. “Justice as Virtue” in Rorty, A. O. (org.). Essays on Aristotle's Ethics. (University of California Press, 1980, p.189-200).

Young, C.M. "Aristotle's Justice" in Kraut, R. (org.). The Blackwell Guide to Aristotle's Nicomachean Ethics. (Blackwell Publishing, 2006, p.179-197). https://doi.org/10.1002/9780470776513.ch8

Zingano, Marco. Ethica Nicomachea I 13- III 8: Tratado da Virtude Moral. Tradução, Notas e Comentários. (São Paulo: Odysseus, 2008).

Zingano, M. Ethica Nicomachea V 1-15: Tratado da Justiça. Estudo, Tradução e Comentários. (São Paulo: Odysseus, 2017). 